\title{
The Two, THE One, THE MANY, THE NONE: Rethinking the Republics of Spaniards and Indians in the Sixteenth-Century Spanish Indies
}

\begin{abstract}
For a half-century, the historiography on Spanish Habsburg rule suggested that the crown envisioned Indies society as best divided into two segregated sociolegal groups: the republic of the Spaniards and the republic of the Indians. This model was popularized by the eminent mid twentieth century Swedish historian Magnus Mörner and has since become a foundational concept in the field. However, using extensive archival evidence, this article suggests that the Mörner Thesis of the Two Republics is flawed. Historicizing sixteenth-century uses of the concept of the republic, it finds that contemporaries conceived of a complex social order in which many political communities such as municipalities and groups of petitioners could overlap within larger meta-republics, such as the Indies republic and the Christian faith-republic. It then turns to subjects' uses of the two republics, noting that this conceptual duality appeared rarely in the petitions of Spanish officials, commoners, Indians, Afro-descendants, and mestizos, and was also rare in royal and viceregal legislation. Moreover, this binary most often served to suggest Spaniards' and Indians' common ground. The article then reflects on other approaches to understanding the Indies' SpanishIndian binary, the place of non-Spanish, non-Indian vassals within republic-thinking, and the staggering complexity of Indies laws, categories, and social interactions.
\end{abstract}

KEYWORDS: Spanish Empire, two republics, caste system, racial laws, indigenous history

I $\mathrm{n}$ the early 1600s, a number of printed treatises and manuscripts theorized about a major legal and social dichotomy within the Spanish Empire: the republics of Spaniards and Indians. ${ }^{1}$ English-language readers might have first encountered these republics in Samuel Purchas's 1625 Purchas his Pilgrimes. He argued that "there is a twofold gouernment in the Indies, one of Spaniards, which is the same with that of Spaine; the other of Indians."

Sincerest thanks to my anonymous reviewers, as well as John Schwaller, Matt DelaMater, and Katrina Swartz (The Americas), Miriam Bodian and Courtney Meador (Institute for Historical Studies), Renate Dürr, Philip Hahn, Heike Bäder, and Andrea Kirstein (University of Tübingen and the Deutsche Forschungsgemeinschaft's SFB-923), colleagues and friends Jorge Cañizares-Esguerra, Ahmed Deidán de la Torre, Kristie Flannery, Juan Carlos de Orellana, and Adolfo Polo y La Borda, as well as Altina Hoti, Dhurata Hoti, and the Zhabjaku family.

1. Readers may find this article's use of 'Indian' somewhat jarring, given it is a famous misnomer and a semantically loaded legal category. Nonetheless, I use the language that many sixteenth-century individuals and groups, including indigenous people, used when presenting themselves within the Spanish justice system (however reluctantly). This avoids confusion for readers, and acknowledges that for contemporaries this term was an inescapable legal reality.

2. Samuel Purchas, Purchas His Pilgrimes (London: William Stansby, 1625), Bk. 7:1421. 


\section{ADRIAN MASTERS}

Englishman was drawing from the 1614 Historia y viage del mundo by the priest Pedro Ordoñez de Zevallos, who observed after having traveled through Peru that the republic of the Spaniards governed itself separately from the "second republic [which] is of the Indians," each "very contrary" to the other. ${ }^{3}$

A sharply contrasting view appeared in Friar Miguel Agia's 1604 printed Servidumbres personales de Indios, which he wrote in Peru at the end of the 1590s. Agia wrote of a single republic - the "república indiana," or Indies republic. ${ }^{4}$ His extensive petition on Peruvian labor and mining exhorted the monarch and his officials to uphold "the common good of the Indians and the Spaniards, for they are all vassals of your Majesty and members of the body of this Republic." 5 The Republic was one, not two. Another theorist, Pedro Mexía de Ovando, wrote a manuscript for publication around 1639 about his experience in Santo Domingo in the 1590s. There, he argued, the Spaniards formed a "Castilian republic," which, despite its name, also included foreigners and blacks. ${ }^{6}$ However, "the Indians do not have a republic," because they could not unite in a "civil body composed of mixed and diverse elements . . . under a single authority, leader, and spirit." ${ }^{7}$ But the confusion did not stop there. An anonymous letter, perhaps by the Peruvian viceroy in the 1630s, characterized the New World as a republic, then posited the existence of the "republic of the Indians," and continued to list innumerable other republics that had no formal institutional or legal existence: the "republic of the citizens" and industrial workers, the "republic of the merchants," the "republic of the miners," and others. ${ }^{8}$

The two republics, the one, the many, the none-how did these overlapping concepts coexist legally, socially, and conceptually in the Indies? Before unraveling this paradox, we must first historicize the idea of the "republic" or "república" within its early modern context, an undertaking that in the context of the Spanish New World remains to this day a "challenge," in the words of one historian. ${ }^{9}$ Most works on the 2000-plus years of the concept's career in Europe focus primarily on tracing a genealogy "from . . . Aristotle, to the Florence of Bruni and Machiavelli, to Venice, England, and the American

3. Pedro Ordoñez de Zevallos, Historia, y viage del mundo del clerigo agradecido don edro Ordoñez de Zevallos (Madrid: Juan García Infanzón, 1691 [1614]), 420r-42lr. All translations in this article are my own. Also, I cite the term 'republics' only if the document uses exactly this term.

4. Fray Miguel Agia, Servidumbres personales de Indios (Seville: EEHA, 1946 [1604]), 106.

5. Agia, Servidumbres, 126. See also 95, 75-76.

6. Libro o memorial práctico, 1639, Biblioteca Nacional de España [hereafter BNE], Mss. 3183, 110, 149. The manuscript takes the form of a draft for publication, but was never printed.

7. Libro o memorial práctico, 1639, BNE, Mss. 3183, 140.

8. V[uestra] Ex[celencia], undated (1630s), Biblioteca Provincial de Sevilla, A 330/122, 263r-265r.

9. José Antonio Aguilar, "Dos conceptos de república," 57-85, in El republicanismo en Hispanoamérica: ensayos de historia intelectual y politica, José Antonio Aguilar y Rafael Rojas, coords. (Mexico City: Fondo de Cultura Económica-CIDE, 2002), here 83. 
Republic."10 Some authors have even discarded the possibility of a history of the republic within the Catholic world entirely. ${ }^{11}$ Many scholars of the New World's Age of Revolutions have nonetheless found the term to be quite widely used in late eighteenth-century Iberian works, especially liberal constitutional writings, and have begun to explore its history within anti-monarchical contexts. ${ }^{12}$ Historians are gradually recognizing the importance of the term in early modern Spain. ${ }^{13}$

Studies of the idea of the republic in the critical sixteenth-century Indies remain in their infancy, likely because scholars have thought republican thinking in this ostensibly hidebound monarchist context impossible. ${ }^{14}$ What is becoming clear is that both Iberian and Indies thinkers spoke of republics constantly, understanding the republic not only as a type of sovereign non-monarchical state but also as a "community constituted into a political body-ruled by justice and law-whose end was the common good, regardless of its form of government." ${ }^{15}$ Early modern Spanish printed juridical treatises drew (often

10. William J. Connell, “The Republican Idea," 14-29, in Renaissance Civic Humanism: Reappraisals and Reflections, James Hankins, ed. (Cambridge: Cambridge University Press, 2000), here 23. See also Francisco Quijano Velasco, Las repúblicas de la monarquia: pensamiento constitutionalista y republicano en Nueva España, 1550-1610 (Mexico City: Universidad Nacional Autónoma de México [hereafter UNAM], Instituto de Investigaciones Históricas, 2017), 55. For a strong critique of the Anglocentrism of many scholars' employments of the term, see Janet Coleman, "El concepto de república: continuidad mítica y continuidad real." Res publica 15 (2005) 27-47.

11. See for instance Antony Black, "Christianity and Republicanism: From St. Cyprian to Rousseau," American Political Science Review 91 (1997): 627-656, especially 652.

12. Aguilar, Dos conceptos," 57-85; Gabriel Entin, "República y federalismo en América del Sur, entre la Monarquía hispánica y las revoluciones de Independencia," in Entre Mediterráneo y Atlántico. Circulaciones, conexiones y miradas, 1756-1867, Antonino De Francesco, Luigi Mascilli Migliorini, and Raffaele Nocera, coords. (Santiago, Fondo de Cultura Económica, 2014), 365-368. Georges Lomné, "De la 'república' y otras repúblicas: La regeneración de un concepto," 1253-1269, in Diccionario político y social del mundo iberoamericano: La era de las revoluciones, 1750-1850. Javier Fernández Sebastián, dir. Madrid: Fundación Carolina, 2009.

13. Manuel Herrero Sánchez, Repúblicas y republicanismo en la Europa moderna (siglos XVI-XVIII), (Madrid: FCE, Red Columnaria, 2017). Xavier Gil, "Republican Politics in Early Modern Spain: The Castilian and Catalano-Aragonese Traditions," 263-288, Republicanism: A Shared European Heritage, Volume 1. Martin van Gelderen and Quentin Skinner, eds. Cambridge: Cambridge University Press, 2002.

14. Francisco Quijano Velasco, "Pensar la comunidad política en la Nueva España del siglo XVI. Un programa de trabajo de historia intelectual," Signos Históricos 20:39 (January-June 2018): 24-49, here 27-28; Quijano Velasco, Repúblicas de la monarquía, 55; Georges Lomné, "De la 'República' y otras repúblicas: la regeneración de un concepto," Jahrbuch für Geschichte Lateinamerikas 45 (2008): 275-296. Ambrosio Velasco Gómez, Republicanismo y multiculturalismo, especially "Republicanismo y multiculturalismo," 84-106 (Mexico: Siglo XXI, 2006). For two accounts which adhere strongly to the Mörner Thesis but allows for nestled republics, see Rafael Sánchez-Concha Barrios, "El cuerpo de república en el pensamiento político virreinal," 101-114, in La tradición clásica en el Perú virreinal. Lima: Sociedad Peruana de Estudios Clásicos, Teodoro Hampe Martínez, coord. (Lima: Universidad Nacional Mayor de San Marcos, 1999) here 101-114 and Annick Lempérière, Entre dieu et le roi, la république: Mexico, XVIe-XIXe siècles (Paris: Belles Lettres, 2004) esp. 49-51. This article deals with postconquest social and conceptual analyses of the new Spanish-Indian order, but does not delve into how contemporaries viewed the 'ancient' indigenous past, or indigenous peoples' social organizations beyond the purview of Spanish officials. In the process, it sidesteps the important debates between Bartolomé de las Casas, Francisco de Vitoria, Juan Ginés de Sepúlveda, and others about whether indigenous societies constituted republics. For these, readers can refer to Quijano Velasco, Repúblicas de la monarquía, 96-208.

15. Quijano Velasco, Repúblicas de la monarquía, 22; Abelardo Levaggi, "República de indios y República de españoles en los reinos de Indias," Revista de Estudios Histórico-Jurídicos 23 (2001): 419-428; José Carlos de la Puente 


\section{ADRIAN MASTERS}

creatively) from Aristotle and Cicero to define republics as harmonious communities of shared interests, often headed by authorities who governed the commons. These republics, despite their unity, could be comprised of heterogenous individuals, families, and other collectives. Some Spanish authors, like Francisco de Vitoria (1532), Juan Fernández Medrano (1602) and Friar Juan de Santa María (1615), envisioned these republics needing leaders, laws, and institutions, while others like Alonso de Castrillo (1521), Furió Ceriol (1559), Jerónimo Castillo de Bobadilla (1597), Martín González de Cellorigo (1600), and Ramírez de Prado (1617) simply defined the republic as any supra-familial social body united by a shared public interest. ${ }^{16}$ Indeed, as we shall see in the pages that follow, many Indies petitioners, treaty-writers, and royal officials invoked the concept to describe communities that could be very concrete or completely theoretical, or anywhere in between, often rendering the term "republic" a floating signifier. ${ }^{17}$

On the rather rare occasions that today's scholars acknowledge and explore the existence of republics within early sixteenth-century Indies' society and policy, they almost always point to the two republics as they appear in the writings of Purchas and Ordoñez. This model has survived in past decades thanks largely to the writings of the eminent Swedish historian Magnus Mörner, who argued influentially in the late 1960s and 1970s that the "crown maintained a strict division between the towns of the Spanish and of the Indians." 18 From this division of local communities arose the dualist notion of Indians and Spanish as socially incompatible, legally distinct, segregated "estates" which officials were to socially segregate from one another. ${ }^{19}$ These two republics constituted a true "system" influenced by the era's "very static concept of society" and formalized legally through "precepts from the metropolitan government."20

\footnotetext{
Luna, Andean Cosmopolitans: Seeking Justice and Reward at the Spanish Royal Court (Austin: University of Texas Press, 2018), 10, 45. For overlapping early modern notions of a 'mixed government' comprising municipal and monarchical government, among other political communities, see Joan-Pau Rubiés Mirabet, "La idea del gobierno mixto y su significado en la crisis de la Monarquía hispánica,” Historia Social 24 (1996): 57-81.

16. José Antonio Maravall, La Philosophie politique espagnole an XVIIe siècle dans ses rapports avec l'esprit de la Contre-Réforme (Paris: Librairie Philosophique J. Vrin, 1955), 89-101; Xavier Gil, "Republican Politics in Early Modern Spain: The Castilian and Catalano-Aragonese Traditions," 263-288, in Republicanism: A Shared European Heritage, Vol. 1, Martin van Gelderen and Quentin Skinner, eds. (Cambridge: Cambridge University Press, 2002), here 263-270; J. A. Fernández-Santamaría, The State, War, and Peace: Spanish Political Thought in the Renaissance, 1516-1559 (Cambridge: Cambridge University Press, 1977), 74-79; and Martín González de Cellorigo, Memorial de la política necesaria y útil restauración a la República de España, José L. Pérez de Ayala, ed. (Madrid, Instituto de Cooperación Iberoamericana, 1991), 123.

17. Quijano Velasco, Repúblicas de la monarquía, 209, 225, Alejandro Agũero, "Las categorías básicas de la cultura jurisdiccional," Cuadernos de Derecho Judicial 6 (2006): 19-58, here 38; Herrero Sánchez, Repúblicas, 18-36.

18. Magnus Mörner, La Corona Española y los foráneos en los pueblos de indios de América (Madrid: Ediciones de Cultura Hispánica, 1999 [1970]), 1, 30.

19. Mörner, Corona, 50.

20. Mörner, Corona, 50, 111.
} 
Despite the crown's "tenacious" efforts to impose this dual sociolegal order, the era's endemic disobedience of royal and viceregal policies and vassals' incessant miscegenation caused the system to collapse. ${ }^{21}$ I call this the Mörner Thesis of the Two Republics. In the past 50-odd years, this binary vision of Indies difference has reigned almost unchallenged. ${ }^{22}$ The dichotomy of Purchas and Ordoñez thus survived, drowning out the more nuanced statements of their contemporaries Agia, Ovando, and many others.

The historiography has since enshrined Mörner's Two Republics model as one of the most singular aspects of the Spanish Empire. Ralph Bauer and José Antonio Mazzotti state, "The Americas were . . . unique in the division of imperial subjects into the 'república de españoles' and the 'república de indios." ${ }^{23}$ María Elena Martínez calls this "one of the most distinctive aspects of Spanish colonial rule." 24 This central historiographical construct is deeply flawed, however, and has not been subjected to archival scrutiny since Mörner first articulated it in the 1960s and early 1970s. The Mörner Thesis ignores the almost total formal absence of the two-republics concept in sixteenth-century imperial decrees and petitions, distorts the era's understanding of the idea of the 'republic,' makes the crown out to be much more invested in social engineering than it was, and vastly oversimplifies Indians' complex statuses within viceregal society and policy.

Some scholars have begun to signal that a reevaluation of the two-republics model is overdue. Already in 1975 Woodrow Borah suggested that this viewpoint actually "ran counter to the thinking of the bulk of the Spanish conquerors and settlers," as well as that of many friars and officials. ${ }^{25}$ Tatiana Seijas has recently noted that the term was "rarely used in the early colonial period." 26 Additionally, Joanne Rappaport has argued for more recognition of "the notion of heterogenous social worlds [which pose] a counterpoint to the persistent myth of two hermetically sealed republics."27 Tamar Herzog has

21. Magnus Mörner, La mezcla de razas en la historia de América Latina (Buenos Aires: Paidos, 1969), 53; Mörner, Corona, 63.

22. In one of the few recent studies focusing specifically on the Two Republics construct, this vision appears entirely intact. See David Tavárez, "República de Indios," Encyclopedia of Mexico: History, Society, and Culture, Michael Werner, ed. (Chicago: Fitzroy Dearborn, 1997), 1255-1259.

23. Ralph Bauer and José Antonio Mazzotti, "Introduction: Creole Subjects in the Colonial Americas," 1-60, in Creole Subjects in the Colonial Americas: Empires, Texts, Identities (Chapel Hill: University of North Carolina Press, 2009), here 22. See also Emily Berquist Soule, "Race and Rule in the Colonial Andes," Latin American Research Review 53:3 (2018): 632-638, here 632.

24. María Elena Martínez, Genealogical Fictions: Limpieza de Sangre, Religion, and Gender in Colonial Mexico (Stanford: Stanford University Press, 2008), 92.

25. Woodrow Borah, Justice by Insurance: The General Indian Court of Colonial Mexico and the Legal Aides of the Half-Real (Berkeley: University of California Press, 1983), 33-35.

26. Tatiana Seijas, Asian Slaves in Colonial Mexico: From Chinos to Indians (New York: Cambridge University Press, 2014), 146.

27. Joanne Rappaport, The Disappearing Mestizo: Configuring Difference in the Colonial New Kingdom of Granada (Durham: Duke University Press, 2014), 70. 


\section{ADRIAN MASTERS}

stated that the construct "never fully exist[ed]," and that these republics "were said to have 'fallen' before they were ever instituted." 28 And most recently, Max Deardorff has noted that the "Latin American colonial historiography is moving away from an earlier emphasis on the "Two Republic" model," by recognizing the complexity of the Indies' many political communities (albeit without directly confronting this concept). ${ }^{29}$

A critical evaluation of the Mörner Thesis and a historicization of the two-republics concept in the sixteenth century are thus necessary. Drawing from the extensive archival sources that many vassals produced throughout the sixteenth century New World, this article begins by contextualizing how Spanish, Indian, some Afro-descendant, and some part-Indian, part-Spanish vassals, as well as Indies officials and the Council of the Indies, employed ideas of 'republics' in sixteenth-century petitions and legislation. It finds that the era's few references to two republics rarely held a straightforward relationship with Mörner's vision of a crown-ordered sociolegal system of Spanish-Indian segregation. To the contrary, when this rare binary vision did appear in petitions and decrees, it more often than not served to underscore that these two very different groups had fundamentally shared interests. Some even employed this dualism to argue against segregation and in favor of these societies' integration. And because of the inherent vagueness of the republic concept, and thinkers' acceptance of the existence of overlapping republics within republics, writers could conjure up countless variations of the common good simultaneously and without risk of contradiction.

Thus while the Mörner Thesis finds support in a very reduced number of documents that invoke the concept of two separate Spanish and Indian republics, other visions of republics, often kaleidoscopically complex, and the place of Spaniards and Indians within them, were far more common. First proving the almost total inapplicability of the Mörner Thesis for sixteenth-century Indies society, this essay then briefly explores some of the historiographical consequences of this model's absence. It gestures towards the richness and fluidity of the Spanish-Indian legal dualism, reflects on new directions for our understanding of Afro-descendant and other vassals' imagined place within Indian and Spanish communities, and points to the intricacy of Indies segregation, which certainly existed at times, albeit under a far less systematic framework and alongside projects of assimilation.

28. Tamar Herzog, "Beyond Race: Exclusion in Early Modern Spain and Spanish America," 151-168, in Race and Blood in the Iberian World, Max S. Hering Torres, María Elena Martínez, and David Nirenberg, eds. (Zürich: Lit Verlag, 2012), here 158.

29. Max Deardorff, "Republics, their Customs, and the Law of the King: Convivencia and Self-Determination in the Crown of Castile and Its American Territories, 1400-1700," Rechtsgeschichte-Legal History 26 (2018): 162-199, 181. 


\section{MANY REPUbliCs: MUNiCIPALITIES, THEIR AFFAIRS, AND THEIR OFFICERS}

The proliferation of Spanish municipalities - some 170 by the early 1600smeant that the 'republic' most often appears in sixteenth-century documents in the context of local government. ${ }^{30}$ Petitions and decrees constantly used the term when describing municipal-level affairs relating to the common good: matters of local justice, policing, land distribution, food, upkeep of roads, and so forth. ${ }^{31}$ From at least the 1520s onward, decrees abundantly reflected this vocabulary. ${ }^{32}$ Municipalities themselves issued abundant acts and ordinances using the term as well. ${ }^{33}$ Countless petitioners and decrees described city councilmen and other justices as the 'officials of the republic.' 34 To be a member of the community who valued the common good over selfish interests made one "very republican" or "invested in the republic." 35 Petitioners and the crown also employed the concept to draw a contrast between city councils' spheres of influence and those of other jurisdictions, especially the royal Indies courts, or audiencias. ${ }^{36}$

30. B. H. Slicher van Bath, Hispanoamérica en torno a 1600, Carlos Lechner, trans. (Alicante: Universidad de Alicante, 2009), 43.

31. Deardorff, "Convivencia," 173. Pedro de Ahumada stated in a 1559 petition to the crown that "one of the most important things is for the republic to have food supplies," referring to Mexico City. Si dice San Pablo, 1559, Archivo General de Indias [hereafter AGI], Patronato 181, R.37, 1170r. In a similar spirit, in 1598 the University of Merchants of Seville accused certain other merchants of acting against the interests of "the government of all the republics" of the Indies. Royal decree, 1598, AGI, México 1093, L.16, 61r.

32. Diego de Encinas, Cedulario Indiano, Alfonso García Gallo, ed. (Madrid: Real Academia de Historia, 2018), see 1525, "towns (pueblos) and republic," 2:358. For royal decrees, see a 1537 order for Tierra Firme, in which the king responded to a petition by the city procurator Hernando de Ceballos, agreeing with him on certain points "relating to its republic.” Royal decree, 1537. AGI, Panama 235, L.6, 132r-132v. Also see Gonzalo Rodríguez, 1592, AGI, Panama 30, N.28.

33. For instance, Cuzco's 1553 and 1572 municipal ordinances both promised to order matters "convenient to the republic." See Ordenanzas antiguas, 1553, BNE, Mss. 3043, 79v and Ordenanzas del Cuzco, 1572, BNE, Mss. 3043, $133 \mathrm{r}-134 \mathrm{v}$.

34. Officials of various sorts, from notaries to municipal officials, were engaged in the "governance of the republic" as officials working in "offices of the republic." See for instance Entre las juntas, 1590s, AGI, Indiferente 1624, R.4, N.14, 812r. See also a 1562 reference by the special royal commission on Indian tribute in Peru that "this land is new... [and] its republics and towns are not yet formed, nor has order been established in them.” Despues que aquí llegué, 1562, AGI, Patronato 188, R.30, point 20. A 1561 royal decree won by Havana petitioner Pedro Venero ordered local officials to be wary that many Indies scribes had not been subjected to royal scrutiny, doing "great damage to the republics." Royal decree, 1561, AGI, Indiferente 425, L.24, 9r.

35. See Memorial de las cosas, undated, BNE, Mss. 3040, 80v-81r, for reference to "Juan del Castillo, a very republican man," 80v. Another group was referred to as "old and rich and senior (antignos), and deeply attached (aficionados) to the republic," in contrast with "new arrivals" who favored their own interests and did "harm to the republic," 81 r.

36. In 1583, the corregidor of Guadalajara juxtaposed the city council's powers to deal with "matters dealing with the republic" with the non-republican jurisdiction of the audiencia. See his 1583 statement that he had received a royal decree banning oidores from intruding into "matters touching upon the republic." El año pasado, 1583, AGI, Guadalajara 30, N.18, 157r. For royal decrees, see Diego de Encinas, Cedulario Indiano, Alfonso García Gallo, ed. (Madrid: Real Academia de Historia, 2018), Bk. 3:40. 
Early in the Spanish conquest and settlement, officials and other vassals suggested that Indians would benefit from similar styles of municipal government. References to Indian town-republics proliferated as petitioners debated whether municipalization was feasible. ${ }^{37}$ Despite widespread initial doubts, in some regions these city councils took root by the dozens, even hundreds. ${ }^{38}$ Through a mix of Spanish force and Indian desire to congregate, heterogenous municipal governments run by indigenous officials began forming in central Mexico by the 1530s, the Yucatan by the 1550s, Peru by the 1560s, and New Granada by the 1590s. Royal decrees, viceregal edicts, and municipal rulings therefore often referred to Indian municipalities (or similar local institutions) as republics. $^{39}$

37. Panama official Licenciado Gaspar de Espinosa wrote Charles V in 1533 that the "Indians of these provinces of Peru" were "people of capacity that have and live in their republic together" and that the emperor should issue a decree encouraging that they remain settled in towns. De un navío, 1533, AGI, Patronato 194, R.19, 88r. Others believed that this municipalization was impossible. Former governor and adelantado Sebastián de Belalcázar wrote the king on November 3, 1549, that "your Majesty will know that the population of these Indians is very different from those of the realms of Peru and New Spain, because those live in republic.” De la ciudad de Cali, 1549, AGI, Patronato 192, N.1, R.53. Sometime in the mid 1570s, Charcas president Lope de Armendáriz suggested to viceroy Toledo that the locals "were not capable to plant and establish ... the order of the republics of Spain" and that any effort was a "fight with nature, with the heavens all of these machinations." El rey, 1570s, AGI, Lima 30, 234r.

38. For central Mexico, see Rebecca Horn, Postconquest Coyoacán: Nahua-Spanish Relations in Central Mexico, 1519-1650 (Stanford: Stanford University Press, 1997), 25; Silvana Elisa Cruz Domínguez, Nobleza y gobierno indigena de Xilotepec (siglos xv-xviii), (Mexico City: FOEM, 2012), 133; Robert S. Haskett, "Indian Town Government in Colonial Cuernavaca: Persistence, Adaptation, and Change," Hispanic American Historical Review 67:2 (1987): 203-231, here 203-207; and James Lockhart, Frances Berdan, and Arthur J. O. Anderson, The Tlaxcalan Actas: A Compendium of the Records of the Cabildo of Tlaxcala (1545-1627), (Salt Lake City: University of Utah Press, 1986), 35-65. For the Yucatan, see Sergio Quezada, Maya Lords and Lordship: The Formation of Colonial Society in Yucatán, 1350-1600, Terry Rugeley, trans. (Norman: University of Oklahoma Press, 2014), 80-89. The crown praised the success of this project in a 1594 royal decree, stating its pleasure with the "good order with which the Indians of that province govern their towns and republics.” Royal decree, 1594, AGI, México 2999, L.3, 129v. The case in the viceroralty of Peru is harder to discern. José Carlos de la Puente Luna has noted that Peru's early Indian cabildos "have not received the same attention as their Mesoamerican counterparts . . . the reality is that we know very little about how [these] cabildos worked in practice," in "En lengua de indios y en lengua española: cabildos de naturales y escritura alfabética en el Perú colonial," 51-113, in Visiones del pasado. Reflexiones para escribir la historia de los pueblos indigenas de América, Ana Luisa Izquierdo de la Cueva, ed. (Mexico City: UNAM, 2016), here 55, n5. However, a cabildo in Cuzco had similar roles, holding elections, punishing local wrongdoers, issuing local legislation or actas, assisting the Church, and allowing descendants of the Inca and commoner yanaconas alike to become voting aldermen. See Registro de elecciones ... de la parroquia de San Sebastián, 1590-1658, Lilly Library, Latin American Mss. Peru, 1535-1929 Series-Manuscript Materials, box 4.

In 1600, Peruvian Indian communities were petitioning to create municipal "republics." See S. Elizabeth Penry, "Pleitos coloniales: 'historizando' las fuentes sobre pueblos de indígenas de los Andes," 439-476, in Reducciones: la concentración forzada de las poblaciones indígenas en el Virreinato del Perí, Akira Saito and Claudia Rosas Lauro, eds. (Lima: PUCP, 2016), here 439, 440, and 466. Officials also took limited steps toward creating Indian municipalities in New Granada. See Jorge Iván Marín Taborda, "Vivir en policía y a son de campana: el establecimiento de la República de Indios en la provincia de Santafé (1550-1604)" (Diss.: Universidad Pablo de Olavide [Seville]), 2017, 253.

39. Many decrees followed a recommendation by the bishops of New Spain to the emperor in 1546 that, since Indians had been hit recently by devastating plagues, officials should "order their towns and republics." Royal decree, 1546, AGI, Indiferente 532, L.1, 150r. When the crown received similar proposals in subsequent decades, it would excerpt the language of this 1546 report, as it did in in New Granada, Charcas, and Mexico, among other instances. See royal decree, 1560, AGI, Santa Fe L.2, 146r-147v; royal decree, 1570, AGI, Indiferente 532, L.1, 150r; royal decree, 1567, AGI, Charcas 418, L.1, 121v; and royal decree, 1550, AGI, México 1089, L.4, 186v-187r. Yucatan protector of the Indians Francisco de Palomino won another May 1579 decree encouraging audiencia officials to help certain Indians implement "order (pulicia) and the arrangement of the republic . . . so that they may decree what is convenient to their republic and government.” Royal decree, 1579, AGI, México 2999, L.2. 
Indian communities subsequently developed new European-inspired vocabularies to describe their communities. The Nahuas often called their community spheres altepetl, the Zapotec yetze or quèche, the Maya cab, the Nuu Dzahui ñun, the Muisca gue, and so forth, with many regional and linguistic variations. In their Spanish-language petitions to the king, the viceroys, and others, Indians also described their municipal sphere of common good using the term 'republic.' Noting the practice of their Spanish counterparts, Indians taking municipal office began to call themselves "officials of the republic" as well. ${ }^{40}$

Many scholars have confused these local Spanish and Indian town-republics by considering them instances of the Mörner Thesis. ${ }^{41}$ The multiplication of Spanish city councils did not directly and immediately prompt contemporaries to embrace widespread views of a unified republic, for each of these had

40. Indian embraces of the term were common. For instance, the Tlaxcalans famously referred to themselves as a republic, and employed the term in their municipal ordinances and actas as well in their many successful petitions before the crown. For examples from Tlaxcala, see Eustaquio Celestino Solís, Armando Valencia R., and Constantino Medina Lima, eds., Actas de cabildo de Tlaxcala, 1547-1567 (Mexico City: Archivo General de la Nación [hereafter AGNM], 1984), N.516 and N.878. See also a royal decree in which the Tlaxcaltecas won a reform for "the government of that republic.” Royal decree, 1585, AGI, México 1091, L.11, 202v-203r. See also the 1554 petition of Coyoacán's Indian leader to the crown: "Don Juan, governor of the town . . . on his behalf and in the name of the republic and university" (the latter term being synonymous with community), in Pedro Carrasco and Jesús Monjarás-Ruiz, Colección de documentos sobre Coyoacán (Volímen primero), (Mexico City: UNAM, 1976), 11. A 1579 royal decree thanked don Antonio Valeriano, one of Mexico City's Indian governors, for having written a 1578 report on his successful evangelization of his people. The decree addressed him as the "governor of the Republic of the Indians of the city of Mexico." Royal decree, 1585, AGI, México 1064, L.2, 7r. The newly founded Indian municipality of Jauja wrote in 1566 that they had "established a cabildo (city council) in our republic," and that they would henceforth seek the "common good of all the republic." Nos el cabildo, 1566, AGI, Lima 121, 45r-47r. Viceregal edicts very often used this terminology as well, using 'republic' interchangeably with concepts like pueblo (town), comunidad (community), and universidad (collective), among others. A 1595 edict, for instance, noted that the Mexican viceroy instructed "the republic of the Indians in the valley of Yrasco" to follow various recommendations of certain Indian leaders of Oaxaca. ${ }^{[40]}$ Other viceregal edicts often referred similarly to those working in Indian municipal positions as "officials of the republic." Viceregal edict, 1591, AGNM Colonial Indios 5, exp.977, n/f. Like their Spanish counterparts, Indian petitioners often used 'republic' interchangeably with concepts like pueblo (town), comunidad (community), and universidad (collective), among others. For Indian vocabularies, see, for the Zapotecs, María de los Ángeles Romero Frizzi, "The Power of the Law: The Construction of Colonial Power in an Indigenous Region," 107-137, in Ethelia Ruiz Medrano and Susan Kellogg, eds. Negotiation within Domination: New Spain's Indian Pueblos Confront the Spanish State (Boulder: University Press of Colorado, 2010), here 132, n35. For the Mixtecs, see Kevin Tarraciano, The Mixtecs of Colonial Oaxaca: Nudzahui History, Sixteenth Through Eighteenth Centuries (Stanford: Stanford University Press, 2001), 103. For the Muiscas, see Hope Henderson and Nicholas Ostler, "Muisca settlement organization and chiefly authority at Suta, Valle de Leyva, Colombia," Journal of Anthropological Archaeology 24 (2005): 148-178.

41. Daniel Nemser, Infrastructures of Race: Concentration and Biopolitics in Colonial Mexico (Austin: University of Texas Press, 2017), 102; Jeremy Ravi Mumford, Vertical Empire: The General Resettlement of Indians in the Colonial Andes (Durham: Duke University Press, 2012), 47-48; Laura A. Lewis, Hall of Mirrors: Power, Witchcraft, and Caste in Colonial Mexico (Durham: Duke University Press, 2003), 50, 79; Matthew D. O'Hara, A Flock Divided: Race, Religion, and Politics in Mexico, 1749-1857 (Durham: Duke University Press, 2010), 32; Guillermo F. Margadant, "Spanish Colonial Policy Towards Indians: The Tlaxcalan Actas (1545-1627), "Texas International Law Journal, 22 (1987): 419-437, here 423425; Norma Angélica Castillo Palma, Cholula: sociedad mestiza en ciudad india (Iztapalapa: Universidad Autónoma Metropolitana, Iztapalapa, 2001), 135. For José-Juan López-Portillo, viceregal policies emerged first, installing Indian municipalities, and officials gradually embraced the notion of Two Republics only afterward-while creating a multiplicity of municipal Indian republics as well. See Another Jerusalem': Political Legitimacy and Courtly Government in the Kingdom of New Spain (1535-1568), (Leiden: Brill, 2017), 129, 194. 
differing praxes and municipal legislation. ${ }^{42}$ For the Indian case, an even greater diversity of municipal forms arose. Far from creating two segregated republics á la Mörner, municipalization created an abundance of kaleidoscopically complex institutions for managing the public good. In a 1536 decree about local justice officials' praxes, the crown mentioned in passing that Indian "pueblos," each a "republic," formed part of the "good of the Republic," meaning "New Spain."43 In a 1571 report to the viceroy, corregidor (field justice) Polo de Ondegardo theorized that Peru was partly comprised of many "republics of the Spanish."44 Few visions of this plurality starkly divided Spanish and Indian interests. For instance, Cuzco's 1572 municipal ordinances claimed to uphold measures "convenient for the government of the republics of these states of your Majesty." 45

High-ranking officials shared this view of provinces and viceroyalties comprising many republics, both Spanish and Indian. In a 1570 letter to the crown, the bishop of Quito proposed a number of reforms, intended to safeguard "the general good of the republics of the provinces of Quito." ${ }^{\prime 6}$ A circa 1594 report to the crown by Mexican viceroy Luis de Velasco referred to a multitude of "republics of Indians" that mutually benefited from cattle ranching along with Spanish ones. But he also referred to a greater "republic" sustained by these many town-republics - the whole-which was by implication the viceroyalty of Mexico itself. ${ }^{47}$

\section{Greater Republics: Provinces, Viceroyalties, the INDIES, CHRISTIANITY, AND BEYOND}

The preceding reference reveals another stratum the republic the concept could occupy: the viceroyalty. In a 1553 petition to the crown, Antonio Rodríguez de Quesada, judge (oidor) of Mexico's audiencia, praised the viceroy as a "true father of this republic." ${ }^{48} \mathrm{He}$ also complained in a 1554 letter that a certain prohibition on Indians providing tribute had caused "great shortages for the

42. The Florentine Nicolao de Albenino, for instance, informed the viceroy in a November 7,1582 , letter that Potosí's "government . . . is very different from those of all the other republics, which have an ordinary government which consists in the justice which proceeds from many years before, [whereas the republic of] Potosí is a new invention." El chasqui ordinario, 1582, BNE, Mss. 3040, 155r. In other cases, municipalities deliberately sought to emulate others. In 1600, a high-ranking official of the Yucatec city of Valladolid, Tomás González Figueroa, successfully petitioned the viceroy to adopt a policy "as is accustomed in other republics." Viceregal edict, 1600, AGNM, México Colonial, General de Partes, exp. 1156, 248r.

43. Encinas, Cedulario Bk. 3:18.

44. Relación histórica acerca de los Incas, 1571, BNE, Mss. 2821, 72r.

45. Ordenanzas del Cuzco, 1572, BNE, Mss. 3043, 133r-134v.

46. Alonso de Herrera, 1570, AGI, Quito 76, N.4.

47. En los puntos, ca. 1594, AGI, México 22, N.155.

48. Al s.or Vissorrei, 1553, AGI Indiferente 858. 
provision of the republic . . . in the cities and villas of all this New Spain."49 Likewise, the viceroyalty of Peru sometimes appeared as a republic. Interim president Lope García de Castro noted in a 1565 edict that various Spanish municipalities had sent petitions complaining that Peru's Indians did not serve their rotational labor, which was "a great inconvenience and damage to the republic" as a whole. ${ }^{50}$ An undated, anonymous petition about Potosí promised to "give your majesty news of the republic of Peru," including mining reforms in the "body of the republic" that would ensure that the "head of the republic," its mineral wealth, could be preserved. ${ }^{51}$ And some time in the 1560s, the lawyer Licenciado Francisco Falcón Díaz petitioned the viceroy of Peru to argue for labor reforms so important "for the sustenance of the republic," which term he used interchangeably with "this realm of Peru." Royal legislation mirrored these usages. One 1535 royal decree sought to reform Mexico's mint, to achieve "what is most convenient . . . to the good of the republic of that New Spain." ${ }^{53}$ Another phrased in similar terms, from 1567, once again sought to reform the mint, using the same language. ${ }^{54}$

A province might also constitute a republic. In a 1569 decree prompted by a legal agent representing a confederation of Spanish cities, the province of the Yucatan appeared as "all the republic." 55 Puerto Rico appeared in a 1574 petition as a "land" (tierra) and a "poor republic." An A 1562 royal decree referred to the Zacatecas mining area vaguely in relation to "all the republic," implying the Nueva Galicia region formed such a unit. ${ }^{57}$

The Spanish Indies was not only comprised of town-republics, province-republics, and viceroyalty-republics, but was also one itself. A 1528 decree contrasted Castile with the "said republic" of the Indies as it ordered officials to be wary of fraudulent petitions for privilege. ${ }^{58}$ Graviel de Osada of Madrid won a February 14, 1556, patent decree featuring a new mill design of "much utility and benefit to the republic of our Indies." A 1565 ordinance recapitulating a 1563 decree won by the Cortes of Castile and dedicated to reducing Indies women's and men's lavish spending on clothing stated, "We desire to see the land founded in good government (policia) . . . so that in

49. En la flota, 1554, AGI, México 68, R.27, N.91, 76r.

50. Para que los alcaldes, 1565, BNE, Mss. 3043, 11 r.

51. Relación del cerro, undated, BNE, Mss. 3040, 10r.

52. Representación de los daños, 1560s, BNE, 3042, 236v.

53. Encinas, Bk. 3:227.

54. Encinas, Bk. 3:414.

55. Encinas, Bk. 3:103.

56. Por otras, 1574, AGI, Santo Domingo 162.

57. El rey, AGI, Guadalajara 30, N.12, 108v.

58. Encinas, Cedulario, Bk. 3:575. 
her the republic is conserved and augmented, and so that it does not fall into diminution nor poverty."59 One witness reported to the Inquisition's visitador Juan de Ovando during his late 1560s investigation of the affairs of the Council of the Indies and New World that it was "necessary to cleanse the Republic of the Indies of indolent men."

There was an even more expansive and inclusive political community, the Christian republic - the ultimate community. ${ }^{61}$ The Indies were only one part of this global faith-republic. Licenciado Gaspar de Espinosa wrote from Panama in 1533 that Peru's mineral wealth could fund war against the Ottomans, resulting in a better "defense [and] conservation of our Holy Catholic Faith, which indebts the Christian Republic" - that is, the besieged Christians of the Old World. ${ }^{62}$ Medical doctor Pedro López wrote the king from Mexico City seeking help to fund a hospital for lepers, which he claimed would be "of use to the entire Christian republic." ${ }^{23}$ Friar Alonso Maldonado, in an undated 1560s petition to the crown, stated that the Indies were comprised of many town-republics, but were also a single community: "the Christian republic of Spaniards and Indians is all one-and all have one king and lord."64 Maldonado argued that as Christians and equals, not only Indians but also Spaniards should be obligated to pay tribute and take up agricultural trades. In one case, a vassal formulated the opposite argument about labor vis-à-vis republics: Indians should provide labor within the faith-republic because the Spaniards had provided them with the spiritual service of salvation. In 1559, conquistador-miner Pedro de Ahumada argued that Spaniards were justly superior to Indians precisely because they allowed for the "growth and ennoblement" of "this Christian republic, which is the foundation of this new Church."

Some writers envisioned a harmonious faith-republic in the Indies' future, suggesting it did not yet exist. Friar Gaspar de Recarte of New Spain stated as

59. Royal decree, 1565, AGI, Indiferente 427, L.30 164v.

60. Licenciado Ramírez de Cartagena, British Library, Add. Ms.33983, 80v.

61. The Christian faith-republic was a centuries-old concept, playing a central role in Saint Augustine's writings in the fourth and fifth centuries. Anthony Pagden, Lords of All the World: Ideologies of Empire in Spain, Britain and France c.1500-c.1800 (New Haven and London: Yale University Press, 1998), 86, notes 96, 100, and 199. See also Paul J. Cornish, "Augustine's Contribution to the Republican Tradition, "European Journal of Political Theory 9:2 (2010): 133-148. For an exploration of this type of republic in 1500s New Spain, see Ana Díaz Serrano, Repúblicas perfectas para el Rey Católico. Los franciscanos y el modelo político de la Monarquía Hispánica en la Nueva España durante el siglo XVI,” 109-136, Oficiales reales: Los ministros de la Monarquía Católica (siglos xvi-xvii), Juan Francisco Pardo Molero and Manuel Lomas Cortés, coords. (Valencia: Universitat de València 2012).

62. De un nabío, 1533, AGI, Patronato 194, R.19, 89r

63. La obligación que tengo, 1570, AGI, México 317.

64. Carlos Sempat Assadourian, "Fray Alonso de Maldonado: la política indiana, el estado de damnación del Rey Católico y la Inquisición," Historia Mexicana 38:4 (April-June 1989): 623-662, here 653. For a partial copy of this letter, see Fray Alonso, 1560s, Bibliothèque nationale de la France [hereafter BnF], Espagnol 325, 236r-237r.

65. Si dize San Pablo, 1559, AGI, Patronato 181, R.37, 1168r. 
much in his dense 1584 manuscript about the legality of forcing Indian groups to provide rotational community labor (the repartimiento). Yes, he noted, "in the Primitive Church, by divine will, the holy Apostles" managed to bring together "peoples of many nations" into a "concordant republic." In the present, officials trampled the Christian republic by disregarding what was good for Indian communities. The result of these abuses was the "sad and helpless manner" in which the "Indian republic," comprised both of Indians and Spaniards, currently found itself. ${ }^{66}$ Thus the Indies-republic had not yet become an apostolic Christian faith-republic, but might in the future.

Royal legislation rarely employed the notion of the faith-republic explicitly. A 1560 decree stated that vassals should aid the inquisitors by providing information for the "benefit of the Christian republic."67 A July 3, 1573, ordinance did so in a number of ways. It repeatedly mentioned the Council of the Indies' desire for a "description of the Christian republic of the Indies." 68 On one occasion, it stated explicitly that it hoped to use this information to reinvigorate the faith. The ordinance stated that "the main cause due to which we have with such diligence ordered the description of the whole orb of the Indies, and especially the Christian republic of them" was to propagate the evangelion. It also stressed the need for local officials to be upright, for "it is not enough for the republic to be well formed in its members, and instituted with good laws and ordinances, if there are not individuals appointed to public offices who can rule and uphold it." 69

Writers sometimes made more exotic references to the existence of other types of republics. In one particularly unorthodox series of usages from 1571, corregidor Polo de Ondegardo wrote (likely to the viceroy) that in highland Peru there was a multiplicity of Indian town-republics, along with a single "republic of the poor and rich," a unitary republic of Spaniards and Indians, and a "republic of the Tahuantinsuyo Indians" in Cuzco, all at once. ${ }^{70}$ In some cases, petitioners also vaguely alluded to a single Spanish-Indian republic. For instance, on March 1, 1576, the Franciscans of the Yucatan described a famine that was causing "great hunger in the republic of the Spaniards and Indians."71 The president of

66. Tractado del serevicio personal, 1584, AGI, Patronato 183, N.1, R.12. Recarte further decried others' beliefs that repartimientos were "convenient to the common good, and that they would prevent the destruction of this republic, if the Spaniards were to be missing from it."

67. It stated that the Cardinal of Sigüenza of the Council of Castile, after discussion with numerous authorities, had requested that the king name Doctor Pedro Moya de Contreras and Licenciado Christival de Cervantes to work on behalf of the Christian republic. See Diego de Encinas, Cedulario, Bk. 1:47.

68. Royal ordinance, 1573, AGI, Indiferente 427, L.29, 34r-v.

69. Royal ordinance, 1573, AGI, Indiferente 427, L.29, 45v.

70. Relación histórica acerca de los Incas, 1571, BNE, Mss. 2821. For Indian town-republics, see $15 \mathrm{v}$ and $52 \mathrm{v}$; for the poor and rich, see $11 \mathrm{r}$; for the Spaniards and Indians, see $57 \mathrm{v}$; and for Tahiantinsuyo, see $50 \mathrm{r}$.

71. El memorial, 1576, AGI, México 101. 
Quito wrote similarly in 1597 that the Indies were made up of a single "republic of Spaniards and Indians."72 And a 1561 petition by the city council of Mexico even stated that there were "three Republics, one of Spaniards, and two of Indians"one urban, the other rural, and "all woven into one another."73 None of these unconventional uses existed in law or juridical theory at the time.

As the previous examples suggest, these innumerable political communities could exist alongside or within one another, without implying their hermetic isolation, let alone antagonism. Indeed, some authors clearly believed in shared Indian and Spanish interests within these republics. A circa 1550 report by Mexico officials regarding indigenous tribute payment suggested that Indian governors should not grant land to Spaniards, as this damaged a single republic which encompassed both groups. ${ }^{74}$ In 1576, a group of dispirited Mexica conquistadors in the Yucatan petitioned the crown for tribute exemptions, arguing they had acted "in the service of our republic," including the peninsula's Spaniards and Indians. ${ }^{75}$ In one of the Florentine Nicolao de Albenino's 1582 letters to the viceroy about the city of Potosí, he argued that "the good of this republic is all one"-that is, that the city was a composite of Spaniards and Indians with shared interests. ${ }^{76}$ And in at least one curious case the town-republic sought measures against both Indians and Spaniards. In 1554, oidor Quesada proposed a number of reforms for the "growth of the Republic" that included building a fortress near the South Sea [the Gulf of Mexico] to thwart future "uprisings of Indians and Spaniards."77

\section{THE REPUblic OF SPANIARDS AND THE REPUbLIC OF INDIANS}

"Republic" was thus a vague term - a tangible sphere of common good like a town, province, viceroyalty, or realm, or a less tangible one like a global faith group, class, or ethnicity. Larger republics also enclosed smaller ones without contradiction. With this understanding of the rich spectrum of sixteenth-century usages of the concept, we can begin to reframe the era's conceptualizations of the republics of Spaniards and Indians, and in doing so, test the Mörner Thesis.

The first of these abstract, binary republics to emerge as an isolated notion was the republic of Spaniards. In a February 7, 1554, report to the king, the Mexican

\footnotetext{
72. En todas las ocasiones, 1597, AGI, Quito 8, R.31, N.132.

73. En todas las cartas últimas, 1561, AGI, México 94.

74. Informe sobre el orden. AGI, Indiferente 2978, N.16.

75. Los indios mexicanos, 1576, AGI, México 100.

76. El chasqui ordinario, 1582, BNE, Mss. 3040, 155v.

77. Viniendo por esta ciudad, 1554, AGI, México 68, R.27, N.91, 89r.
} 
viceroy employed this version of the term, along with an array of other 'republics,' to press for various reforms. He stressed how he had sought to avoid "becoming enemies with the republic of Spaniards," and fretted: "I believe in the name of this city and the whole republic of the Spaniards of all of this New Spain [their petitioners] will go plead that Your Majesty grant them the privilege of implementing the repartimiento." $78 \mathrm{He}$ also included references to how Spaniards and Indians administered "their republics," and praised Indian municipal officials "who are in charge of the republic" and were encouraging the "growth of the republics." 79 We can surmise that the viceroy's conceptual republic of Spaniards was the sum and alliance of all Spanish municipal procurators, a political republic that arose situationally but did not constitute a permanent collective. For others, the republic might be more concrete and also might transcend mere political activity. Franciscan friar Toribio de Benavente wrote in 1555 that Bartolomé de las Casas's polemical vision of wicked Spaniards "defames a republic and a nation." 80

The republic of Indians had also appeared as a stand-alone concept in some petitions by the late 1550s. A group of Indians, likely writing the Peruvian president in the late 1550 s or 1560s, claimed to speak "in favor of their republics." They also stated that they wished to propose reforms that concerned "the whole republic of the Indians." 81 In other words, theirs was a political community comprised of many town-republics.

High officials also employed the term to mean a meta-republic within the viceregal community. Sometime in the mid-to-late-1550s the official Hernando de Santillán wrote from Lima or Chile complaining that officials had failed to attend to the "conservation of the republic of the natives." 82 The Mexican viceroy titled his 1568 report "The matters which have need of remedy regarding the Republic of the Indians of the land of Mexico, and of that Realm," addressing issues related to alleviating labor demands and separating Spaniards from Indians except in exceptional circumstances. ${ }^{83}$ The governor of Chile Martín García de Loyola wrote the crown in 1581 about mail reforms benefiting the "republic of these natives," and "the Republic of the Indians," while stating also, about Peru, that its "republic is comprised of people on the move" (gente de paso). His Peru was a multilayered composite of republics, including one of natives. ${ }^{84}$ This formulation was rare in crown legislation. One

\footnotetext{
78. En los navíos, 1554, AGI, México 19, N.13, 3r and 8v.

79. En los navíos, 1554, AGI, México 19, N.13, 13r.

80. Gracia y mysericordia, 1555, AGI, Patronato 294, N.1, 4v.

81. Memoria de las cosas, 1550s or 1560s, AGI, Indiferente 857.

82. La beninidad, mid-to-late 1550s, AGI, Patronato 231, N.7, R.14.

83. El navío de aviso,1568, AGI, México 19, N.52.

84. Carta de Martín García de Loyola, BNE, Mss. 3040, 54r, 57r, 59r.
} 
Peruvian viceroy's petitions prompted a 1589 royal decree that stressed the abolition of Indian servitude and the introduction of fair labor wages, which the crown agreed would be good "for that republic," that is, for the Indians. ${ }^{85}$ This may have been the sole piece of sixteenth- century legislation to refer to the Indian republic in isolation.

This brings us to the historiography's vaunted two republics. Where did this conceptual binary come from, and what attributes did the crown, officials, and vassals assign it? Numerous scholars have erroneously stated that the king, the Council of the Indies, and high-ranking officials sought to implement the two republics immediately upon conquering the Indies. Others have asserted that this sociolegal construct was already in full swing by 1530s. A smaller number of scholars have correctly indicated that it emerged sometime in the 1550s, or even later. $^{86}$

Indeed, the earliest formal reference I have found to this dichotomy is in Friar Toribio's May 15, 1550, petition to the crown. The influential Franciscan stressed the need to balance Spanish and Indian interests, for "it is just that in the republic there be differences of persons and estates . . . like there are, in Spain, gentlemen and hidalgos who do not pay tribute." Similarly, in the Indies it was only natural that there would be "people who would be free and exempt" of labor burdens. However, he warned that the crown should be wary lest "providing for the republic of the Spaniards, that [republic] of the Indians be depleted and consumed." 87 This was likely not the first time anyone thinking about the Indies considered the two republics, of course, given what we know about how vague and adaptable this concept could be to virtually any context. Its appearance in writing was nonetheless significant, for it shows that influential figures had begun to reflect on this conceptual binary by the early 1550 s.

Subsequent writings featuring the two republics rarely corresponded with the Mörner Thesis of incompatible interests and rigid segregation. The Franciscan order's undated instructions for its Madrid legal agent from the second half of the sixteenth century stated that Indians should not mix their municipal governments with the "republic of Spaniards," considering that they were "very

85. Royal decree, 1589, AGI, Lima 570, L.15 25r.

86. Kathryn Burns, Convents and the Spiritual Economy of Cuzco, Peru (Durham: Duke University Press, 1999), 21; R. Douglas Cope, The Limits of Racial Domination: Plebeian Society in Colonial Mexico City, 1660-1720 (Madison: University of Wisconsin Press, 1994), 3, 16; J. I. Israel. Race, Class, and Politics in Colonial Mexico (New York: Oxford University Press, 1975), 14-15; Ben Vinson III, Before Mestizaje: The Frontiers of Race and Caste in Colonial Mexico (New York: Cambridge University Press, 2018), 3; López-Portillo, Another Jerusalem,' 19; Tavárez, "República de Indios," 1256; Robert C. Schwaller, Géneros de Gente in Early Colonial Mexico (Norman: University of Oklahoma Press, 2016), 56, 80-81; Nemser, Infrastructures, 102; O’Hara, Flock, 29.

87. Gratia et misericordia, 1550, AGI, México 280. 
different." ${ }^{\$ 8}$ More explicitly, the Italian mercantile official Luis de León Romano wrote from Mexico City in 1553 that the crown should create Spanish-only towns and prevent Spaniards from living in Indian ones so that "these republics will divide in a manner that one will not aggravate or aggrieve the other." He did not believe that this division of republics currently existed in New Spain. Spanish and Indian societies were already deeply intertwined-the Italian wrote of numerous disorderly Indian town-republics invaded by Spaniards. But Indians also corrupted Spaniards. He complained that the "young men of our republic" grew up in the immoral Indian marketplace, and that this ill-mannered youth "in our republic as well as that of the natives" showed signs that they might eventually grow disloyal to the crown. Solutions eluded officials because the "republic" in general (perhaps Indian municipalities, Mexico City, the viceroyalty, or the Indies) had "not been understood due to being different from all these others which exist among mankind."89

Another report that envisioned these two worlds as quite antagonistic came from Charcas treasurer Diego de Robles. He informed the crown sometime in the 1590s that while the Indies formed a united republic, comprised of many town-republics, the Council of the Indies should nonetheless understand that "in those Realms there are two communes of republics, the one of Indians, and the other of Spaniards, each one contrary in every way to the other." However, they were not to be completely separated, for without one another they "cannot provide subsistence to themselves, or sustain themselves." For this reason, the crown had to encourage measures favorable to the "republic with less strength and aid" - that of the Indians. ${ }^{90}$ Sometime in the late 1590 s, the legal agent Domingo de Eraso alleged on behalf of unspecified Chilean clients that the province's governor had "found the republic of the said Indians destroyed" at the hands of Spaniards, and suggested the Council offer more financial support to the protectors of Indians. ${ }^{91}$ Perhaps no communication was more vehement than Antonio Freire's 1593 petition from Quito, which alleged that local Spanish justices grievously abused Indians and that absolute segregation was imperative. He fumed, "The Spanish republic is the mortal enemy of the Indians," and its officials “impoverish the republic of the natives."92

At least two officials suggested that segregation could contribute to the common good of both Indians and Spaniards. Charcas president Juan López de Cepeda

88. Memorial para el señor contador, undated, BnF, Espagnol 325, 267r.

89. R. Ricard, "Un document inédit sur la situation du Mexique au XVI siècle," 556-562, Miscelânea de estudos em honra de d. Carolina Michäelis de Vasconcellos, profesora de Facultad de Letras da Universidade de Coimbra (Coimbra: Imprensa da Universidade, 1933), here 561.

90. Entre las juntas, 1590s, AGI, Indiferente 1624, R.4, N.14, 812r-812v.

91. Domingo de Eraso. AGI, Indiferente 1415.

92. Relación summaria, 1593, AGI, Quito 24, N.2, no folio. 
promised in a 1585 letter to implement a royal decree forcing encomenderos out of Indian towns, a measure he considered "very in the service of God and your majesty and the good of one republic and the other." ${ }^{\text {93 }}$ In another 1588 report, he suggested moving against "so many Spanish vagrants," not only to help Indians but to remedy the "damages done to the republics of Spaniards and Indians." 94 In 1583 an oidor of Santa Fé, Francisco Guillén Chaparro, suggested that while Spaniards often invaded Indian lands, this problem could and should be solved by officials' careful division of local property, "for these two republics of Spaniards and Indians [both] require sustenance."95

\section{The Two Republics, Beyond ANTAgonism AND SEGREGATION}

Aside from this handful of invocations of the two republics, which do conform quite closely with the Mörner Thesis, most suggested Spanish and Indian republics shared fundamentally common interests and should not be segregated. Some even suggested that these two societies were converging, for the better. In his 1551 letter to the crown, Guatemalan oidor Tomás López Medel used the binary not to describe two permanently separate societies, but to state instead that though "these two republics of the Spaniards and natives" were quite different they would hopefully become so "together and so fraternized" that any damage done to one would befall the other. ${ }^{96}$ In 1554 the Franciscan Juan de San Francisco suggested that the Council attempt to issue certain reforms to "provide [policies] for that which concerns the good government of these two republics" in order to "join and confederate these two so very different nations." 97

Another petitioner, Friar Cristóbal de Ortega, reflected longer than most on the nature of this antagonism. He suggested that great opposition and mutual support coexisted in the two republics, and proposed an intricate solution allowing for Spaniards and Indians to harmoniously coexist. Writing from somewhere in Mexico in the second half of the sixteenth century, Ortega noted that he and certain other vassals favored a "New Spain divided into two republics, one of Indians and the other of Spaniards." The republic of Indians currently had its own ordinances and community practices. This republic was also legitimately inhabited by some Spanish individuals, however. He noted,

93. La infinita clemencia, 1585, AGI, Charcas 16, R.24, N.115.

94. En toda ocasión, 1588, AGI, Charcas 16, R.27, N.143, point 21.

95. Es cosa cierta, 1583, AGI, Patronato 27, R.34.

96. Por otra letra, 1551, AGI, Guatemala 9A, R.18, N.77.

97. El gran deseo, AGI, Mexico 280. 
"In this republic, all the Spaniards who contribute to or are necessary for the conservation of Christianity . . . and good government" were "useful persons." Consequently, some Spaniards-churchmen and officials especially-could be legitimately "incorporated and make a body" with the republic of Indians. For Ortega, there was also a separate republic of Spaniards, which included anyone who did not help Indians "by office nor by desire," especially self-serving "miners, merchants, and other sorts of people who only procure their own comfort." While noting that matters were currently strained between these two republics due to many Spaniards' lack of concern for the Indians' well-being, the friar could imagine future harmony and integration serving "the common good not only of the Spanish republic but also that of the Indians." Even in the present, the friar noted, "they eat in our homes, and we in theirs." 98

Some went further than to suggest limited interests that would cross republics. Officials might employ the dichotomy to discourage legal segregation outright. In 1590, oidor Alonso de las Cabezas de Meneses criticized those who believed Spaniards should distance themselves from Indians and cease to force them to provide labor. This would return Indians to their idolatrous ways and "destroy at every point the Spanish republic, and that of the Indians would be destroyed as well." Labor encouraged Indians to become less like "beasts" and help them "pray, make the sign of the Cross, be on their knees, dress in clothes, wear shoes, sweep the house, serve the table." 99 Licenciado Francisco de Auncibay echoed this when he wrote to the Council of the Indies in a 1596 report about the Quito and New Granada area that a certain decree banning Indians from cattle-ranching was "destruction for the Spanish republic, and not less for the Indian one." Indeed, those who ranched "are richer, healthier, more plenteous of children and goods, and more Catholic." He concluded that "in this matter one cannot create a general rule. ${ }^{\prime 100}$

One official argued on the eve of the seventeenth century that anyone wishing to rigorously segregate the Indies plotted the realm's undoing. Quito president Manuel Barros de San Millán stated that "now the republic of Spaniards and that of the Indians has been united and incorporated, in such a manner, that neither one nor the other could be conserved if we dismembered them." He employed this binary to defend compulsory Indian labor, which forced interaction between both societies. These unequal duties, he insisted, benefited "the public good that runs throughout the conservation of both republics."101

98. No title, no date, AGI, Indiferente 857.

99. Por algunas cédulas, 1590, AGI, Quito 8, R.24, N.79.

100. Parecer del Lic. Nuncibay (sic), 1596, AGI, Indiferente 2987, 106v.

101. El secretario Pedro, 1597, AGI, Indiferente $2987,57 \mathrm{v}, 63 \mathrm{v}$. 
Other writers sidestepped the issues of antagonism and segregation completely, and instead suggested there were many policies that would unambiguously benefit both republics. In 1552, Friar Toribio and his fellow Franciscans reported that they had received royal decrees relating to "the good government of these two republics, Spanish and Indian." They complained that viceroy-oidor jurisdictional conflicts were hurting "these two republics." ${ }^{\prime 02}$ The friar wrote again from Tlaxcala in $\mathbf{1 5 5 5}$ that there were certain vacant fields that both groups could graze upon for the benefit of "both republics." 103 In other words, while Mexico's Franciscans were important pioneers of the Two Republic model, they did not always use it to mean two isolated, antagonistic spheres. $^{104}$

Many others agreed with this more harmonious vision. A member of the Puebla municipal council, Gregorio Díaz de Vargas, promised his 1556 proposals to the king would "benefit the common things of the Spanish republic and of these natives." While his letter also referred to many Indian and Spanish town-republics, he also believed that certain agricultural reforms might be of "benefit to both republics, Spanish and Indian (yndica)."105 Similarly, the municipality of Valladolid informed the crown in 1576 that Yucatán governor Francisco Velázquez de Gijón had "bested his predecessors in his good governance of these two republics, ours and that of the natives."106 In another similar instance, the city of Mérida complained in 1579 that the Yucatan had no wheat and that many had resorted to eating cooked corn and tortillas. They stated that the governor had been working to remedy the problem and "has understood the needs of both republics, natives and Spaniards. ${ }^{.107}$ In 1595, a schoolmaster reported from New Granada that a visitador who spent "fourteen months" in the province "leaves both republics of Spaniards and Indians organized."

By the final third of the 1500s, high-ranking officials increasingly echoed these less antagonistic interpretations of the two republics. Mexico's criminal judges (alcaldes del crimen) reported in 1570 that audiencia officials worked "in the service of God and your Majesty and the republics of Spaniards and Indians." 109 The president and oidores of Quito stated in 1590 stated that an

102. Por cartas, 1552, Archivo Histórico Nacional, Spain, Diversos-Colecciones 23, N.65, 1 r.

103. Gracia y mysericordia, 1555, AGI, Patronato 294, N.1, 4v.

104. This is not to say they did not favor segregation in other writings or in other circumstances, but rather to say that this particular vision of Two Republics was not segregationist.

105. Como criado, 1556, AGI, México 168, 178r-183v.

106. Por cumplir, 1576, AGI, México 94.

107. Nuestras afliçiones, 1579, AGI, México 364, 121r-v.

108. Despues que el Lic[enciad]o, 1595, AGI, Santa Fe 17, R.12, N.114. See also Carmelite friar Elías de San Martín's 1598 petition, which asserted that the order's deeds "benefit of both republics of Spaniards and Indians." No title, 1598, AGI, Indiferente 1417.

109. Los alcaldes, 1570, AGI, México 68, R.27, N.91, 282r. 
investigator was "seeking to settle matters in everything relating to the republic of Spaniards as in that of Indians." 110 Pedro de Vizcarra, lieutenant general of the Chilean governor, claimed that he sought to defend "the tranquility desired [by] both republics."111

The very same officials who sometimes employed an antagonistic two-republics model often modulated their views in other reports. Charcas's president Cepeda, who earlier sought to remove Spanish vagrants from Indian towns, also gave certain Spaniards Indian land. He wrote in 1592 that the "growth in the Republic of Spaniards" was becoming a burden on Indies society, so he had begun redistributing land to poor Spaniards and Indians to increase agricultural output "for the provision of their republic and that of the Indians." 112 These lands had belonged to overly powerful caciques, but now he was redistributing parcels "to both republics of Spaniard and Indians . . . for the good of both republics."113 The same official who had previously used the two-republics model to justify partial segregation of certain Spaniards now encouraged them to live on Indian land, albeit as peaceful farmers, not harmful vagrants.

By the final quarter of the century, several Mexican viceroys had also made occasional references to the two republics. However, they too implied that this binary did not preclude shared interests. In a private 1580 letter, Viceroy Martín Enríquez wrote his successor that within the republic-viceroyalty there were "two republics to be governed in this land, which are Indians and Spaniards"- and that the Indians required special care and protection. ${ }^{114}$ This did not entail insurmountable antagonism. Only a few years earlier, in 1577 , Enríquez himself had issued an edict instructing local judges to supervise harvests "for being in the utility of the natives and the republic of Indians and Spaniards." 115 His successor likewise suggested in 1590 that his elimination of field justices with jurisdiction over roadways and stores (jueces de caminos $y$ ventas) had benefited the "republic" of New Spain, as well as "the republics of Indians and Spaniards." 116 He wrote again in 1590 that his predecessor, "with his soft government of this New World" had benefited "both republics of Spaniards and Natives . . . with all the peace and tranquility that could be desired."117 And in 1594 he reported that the public pasturelands around the Valley of Mexico had "provided sustenance for the republics of Indians . . . and

110. En la flota, 1590, AGI, Quito 8, R.24, N.81.

111. En todas ocasiones, 1596, AGI, Indiferente 1413.

112. En cumplimiento, 1592, AGI, Charcas 17, R.3, N.28.

113. Como V[uestra] M[ajesta]d, 1593, AGI, Charcas 17, R.4, N.31.

114. Instrucción, 1580, BNE, Mss. 8553, 31r.

115. Viceregal edict, 1577, AGNM, México Colonial, General de Partes 3, exp. 14, 8v-9v.

116. Después que despaché, 1590, AGI, México 257.

117. Por tener entendido, 1590, AGI, México 71, R.4, N.54. 
that of the Spaniards," and that because of this "the republic"-that is, all of Mexico-“can be sustained."118

\section{THE REPUBLICS IN LEGISLATION}

There was only one moment - albeit a very important one-in which the king and the Council of the Indies explicitly endorsed the existence of two republics in their internal paperwork. It transpired in the late 1560s and early 1570s, during inquisitor Ovando's investigation and his subsequent reforms of the council as its president beginning in 1571 . Having discovered that council ministers were often ignorant of the many policies their predecessors had issued in previous years, Ovando proposed creating a thematic compilation to enable the orderly retrieval of past decrees for easier reference to them. ${ }^{119}$ By 1571, his subalterns had already outlined seven volumes: (I) the Church and spiritual governance, (II) temporal governance, (III) litigious justice (justicia), (IV) the Republic of Spaniards, (V) the Republic of Indians, (VI) royal finance, and (VII) navigation and trade. ${ }^{120}$ President Ovando's subalterns managed to produce at least the first of these books, the manuscript First Book of the Spiritual Governance of the Indies. These officials also produced an index, cover, and draft page of the third book, the Republic of Indians, and two sheets of an early draft of an index of the fourth book, the Republic of the Spaniards. ${ }^{121}$ But did this mean Ovando believed the Indies was comprised of two republics, or that he wished to enforce such a distinction through rigid segregationist policy?

In a report to the king, he stated his intention to "remedy all the things of that republic" - that is, the Indies republic. ${ }^{122}$ In the preamble to the first book, he employed even more eclectic uses of the category. The Indies were increasingly turning to municipal life "in the form of the republic." The New World also comprised "all one church, one kingdom, and one republic-we desire that in the entire Indies a single law be kept." ${ }^{.23}$ One 1573 ordinance bearing his signature ordered vassals to submit "description[s] of the Christian republic of the Indies." ${ }^{124}$ In other words, president Ovando's thematic organization of

118. En los puntos, 1594, AGI, México 22, N.155.

119. Marcos Jiménez de la Espada, El código ovandino (Madrid: Manuel G. Hernández, 1891), 9.

120. Jiménez, Código, 9.

121. Juan Manzano Manzano, Historia de las recopilaciones de Indias, vol. I, Siglo XVI (Madrid: Ediciones Cultura Hispánica, 1950), 141-145. See also an index of the Republic of Spaniards book: Libro 4 de la Rep., AGI, Indiferente 857. This index clearly understood the 'republic' to mean the municipality, despite its title. Its sections included Title 1, "Conquistadors"; Title 2, "of cities and villas"; Title 3, "of municipalities"; Title 6, on agriculture; Title 7, on ranching; and Title 8, on public works.

122. Jiménez, Código, 11-13.

123. Libro primero de la gobernación espiritual, ca.1571, BNE, Mss. 2935, 2v.

124. Royal ordinance, 1573, AGI, Indiferente 427, L.29, 34r-v. 
Indies laws into two republics was a reflection of neither the sociolegal existence of these two bodies, nor of the crown's intention to enforce them-the reality was much more complex. ${ }^{125}$

The record suggests president Ovando's already ephemeral definition of a legislative two-republics duality did not survive his 1575 death. Only three extant royal decrees refer to the two republics. The first is a 1573 ordinance ordering officials to ensure that their own jurisdictions be well organized before undertaking new conquests "for the perpetuity of both republics."126 The second is a 1574 decree responding to a viceroy's suggestion that certain Indians should work in mines for Spaniards because "one republic cannot sustain itself without the other."127 The third is a decree responding to viceroy Velasco the Younger's 1590 petition that wine sellers and cattle ranchers with monopolies lose their licenses to benefit the "utility of the republics of Indians and Spaniards."128 These decrees underscore these republics' shared interests, rather than urging their separation. Lastly, of over 10,000 surviving Mexican viceregal edicts, only one references the two republics. The 1578 order by viceroy Enríquez sought to restore a ban on reselling bread, which he thought beneficial "both to the republic of Spaniards as with the natives." 29

Another measure of whether the Council of the Indies sought to implement this duality was its first official printed decree compilation, Diego de Encinas's 1596 Provisions, Decrees, Chapters of Ordinances, Instructions, and Letters Issued and Dispatched in Different Times by Their Highnesses. Encinas began his work in the year of president Ovando's death, and 21 years later produced a mammoth four-volume book, of which the council distributed 500 copies to peninsular and Indies officials. ${ }^{130}$ Only two of its entries mentioned the two republics. These were the 1573 ordinance on new conquests, and a 1574 decree to the Mexican viceroy concerning Indian work in the mines (both discussed above). These mentions were fleeting and lacking in detail. On 19 further occasions, Encinas included excerpts referring to republics that vaguely implied the "common good," without further explanation. ${ }^{131}$ Another 19 instances alluded to town-republics-17 for Spaniards' municipal affairs, and two regarding

125. Deardorff, "Convivencia," 174.

126. Encinas, Cedulario, Bk. 4:235-242.

127. Encinas, Cedulario, Bk. 4:315.

128. Despues de que despaché, 1590, AGI, México 22, N.16, point 10.

129. Viceregal edict,1578, AGNM, Ordenanzas 2, 221r/7r.

130. Consultas. AGI, Indiferente 745, N.102a and 102f.

131. For these vague references, see Encinas, Cedulario, Bk. 1:163, 205, 208, 273, 358, 364, 430; Bk. 2:35, 176, 241, 353, 370; Bk. 3:48, 50, 53, 63, 103; and Bk. 4:242, 297. 
Indians. ${ }^{, 132}$ One referenced the province-republic of the Yucatán, and three more described New Spain. ${ }^{133}$ The compilation also made one reference to the republic of the Indies and another to the Christian republic. ${ }^{134}$ By 1596, then, the council had not made the two-republics binary even a minor part of its massive legislative output, using the duality only in a handful of non-antagonistic instances, largely if not entirely in response to petitioners' recommendations and requests. The monarchy, far from pressing this division as Mörner suggested, was almost entirely indifferent and passive in its development.

\section{BEYOND THE TWO REPUBLICS}

As of 1600, then, the two republics as the Mörner Thesis conceives of them did not exist in the New World as a systematic legal effort to segregate Spaniards from Indians. The two republics were far from "perfectly juridically defined" during this critical century, for they lacked almost any legislative, or even conceptual, heft. ${ }^{135}$ Doing away with the Mörner Thesis promises to give historians new perspectives into Spanish-Indian relations, but also throws us headlong on the problem of how to better describe Spanish and Indian legal categories and social realities.

Spaniards did consider Indians universally different in important respects, in spite of their obvious similarities. Yes, the Indians were humans, vassals, and potential Christians. Yet they looked different, spoke different languages, and lacked more than a few generations of Christianity in their family lines, at best. Most Spaniards also accepted that most Indians owed more in tribute to Indies society, though we have also seen that controversies raged about this issue.

Many vassals also believed that Indians should not cohabit with Spaniards under any circumstances, though this too was highly controversial. On the surface, the Indies' institutional arrangements do favor the Mörner Thesis, as they seem to divide Indian and Spanish affairs rigorously, and in this article I have shown that municipalization of Spanish and Indian communities did indeed create an illusion of rigid legal segregation. Spanish city councils offered Indians no

132. For Spanish municipalities, see Encinas, Cedulario, Bk. 1:77, 188, 368; Bk. 2:112, 182, 358, 359; Bk. 3:2, 3, 28, 40, 40, 41, 227; and Bk. 4: 236, 237. For Indian municipalities, see Bk. 1:318; and Bk. 3:18.

133. Encinas, Cedulario, Bk. 3:227, 18, 414.

134. Encinas, Cedulario, Bk. 1:47, Bk. 3:575.

135. Enrique González González, "Mecenazgo y literatura: los destinos dispares de Juan de Narváez y de Sigüenza y Góngora," 17-38, Carrera, linaje y patronazgo: Clérigos y juristas en Nueva España, Chile y Perú (siglos XVI-XVIII), here 17, Rodolfo Aguirre Salvador, coord. (Mexico City: UNAM, Plaza y Valdés, 2004); For an almost identical statement, see Thérése Bouysse-Cassagne, "In Praise of Bastards: The Uncertainties of Mestizo Identity in the Sixteenth- and Seventeenth-Century Andes," 77-97, in Inside and Outside the Law: Anthropological Studies of Authority and Ambiguity, Olivia Harris, ed. (New York: Routledge, 1996), here 77. 
membership roles and few opportunities for the redress of grievances. Indians' rare appearance in municipal minutes was not official policy, however, but was rather a reflection of most city councils' weak authority. ${ }^{136}$ It was almost always wiser to petition a higher authority. Caciques and Indian municipalities likewise had restricted memberships and generally did not have authority over Spaniards.

In many other jurisdictions authority was mixed and messy, although viceregal justice, on its surface, maintained the Spanish-Indian distinction. Viceroys and audiencias offered separate and more affordable channels for justice-seeking Indians, often providing translators and special government officials such as protectors and defenders of Indians. ${ }^{137}$ And viceroys issued special policy and privilege edicts for Indians. ${ }^{138}$ In practice, however, both Spaniards and Indians sought justice through many of the viceroyalty's legal paperwork channels and often had an impact on one another's affairs. ${ }^{139}$ Other local justice officials, like corregidores and municipal justices, could resolve both Spanish and Indian cases and conflicts. ${ }^{140}$ Episcopal inquisitors had jurisdiction over both Spaniards and Indians until the crown's official establishment of the Holy Office in 1571, which exempted Indians from inquisitorial trials but still invited their testimonies and accusations against Old Christians. ${ }^{141}$ Following in the inquisitorial tradition, Spanish visitadores universally encouraged Spaniards, Indians, and others to air grievances against officials. ${ }^{142}$ Lastly, the Council of the Indies dealt with both Spanish and Indian lawsuits and

136. For instance, in 1560 don Felipe Cantopa and don Juan Sona, "Incas and municipal justices (alcaldes) among the Indians," convinced the cabildo to restrict Indian women's contacts with "Spaniards . . . and mestizos and other people" and forbade them from dressing in European clothing. El Libro del Cabildo de la Ciudad del Cuzco, Laura González Pujana, ed. (Lima: Instituto Riva-Agüero, 1982), 112-113. For the term alcalde, see John F. Schwaller, "Alcalde vs. Mayor: Translating the Colonial World," The Americas 69:3 (2013): 391-400.

137. For this expansive 1500s collection see the Libros de indios, AGNM, Sección Virreinal, Indios 2-6.2. For protectors. see Charles Cutter, The Protector de Indios in Colonial New Mexico, 1659-1821 (Albuquerque: University of New Mexico Press), 1986, 15; and Carmen Ruigómez Gómez, Una politica indigenista de los Habsburgo: el Protector de Indios en el Perú (Madrid: Ediciones de Cultura Hispánica, 1988), 67.

138. Libros de indios, 1500s, AGNM, Sección Virreinal, Indios 2-6.2.

139. Spaniards appear often in the Indios section, as well as in other sixteenth century collections of viceregal edicts such as AGNM Mercedes, Tierras, General de Partes, and others.

140. Carmen Ruigómez Gómez, Una política indigenista, 68.

141. See for instance don Pedro Moya de Contreras' October 10, 1576 Edict of the Faith: "All people of any state, class, or condition... within the present confines of this kingdom of New Spain should come forth and denounce any and all crimes against the faith." The Inquisition in New Spain, 1536-1820: A Documentary History. John F. Chuchiak IV, ed. and trans. (Baltimore: Johns Hopkins, 2012), 108. For episcopal inquisitors, see Inga Clendinnen, Ambivalent Conquests: Maya and Spaniard In Yucatan, 1517-1570 (Cambridge: Cambridge University Press, 2003), 61, 76.

142. Ismael Sánchez Bella, Derecho Indiano: Estudios I. Las visitas generales en la América española (Siglos XVI-XVII), (Barañaín-Pamplona: Universidad de Navarra, 1991); José Miranda, El tributo indígena en la Nueva España durante el siglo XVI, 2nd ed. (Mexico City: El Colegio de México [1952] 2005), 115, 137, 294, 319-321; Germán Colmenares, La Provincia de Tunja en el Nuevo Reino de Granada. Ensayo de historia social (1539-1541), 3rd ed. (Bogotá: Tercer Mundo Editores [1970] 1997), 6-8, 38-43, 56-67, 98, 199-273; Garci Díez de San Miguel, Visita hecha a la provincia de Chucuito, Waldemar Espinoza Soriano, ed. (Puno: Corporación MERU, 2013); Waldemar Espinoza Soriano, Huaraz: poder, sociedad y economía en los siglos xv y xvi (Lima: Universidad de San Marcos, 1978); Cristóbal Landázuri, Visita y mumeración de los pueblos del Valle de los Chillos 1551-1559 (Quito: Marka, 1990); Juan Manuel Pérez Zevallos, La visita de Gómez Nieto a la Huasteca, 1532-1533 (Mexico City: CIESAS, 2001); and José Augusto Gamboa Mendoza, El 
petitions. In theory and in practice, the justice system's institutional boundaries were rarely tidy.

The Mörner Thesis also does not accurately describe the Indies' sociolegal realities. The Spanish-Indian binary was indeed omnipresent, but it still allowed vassals to think in complex ways about the Indies and all other crown vassals. The era's countless legal terms attest to this acceptance of legal diversity. All legislative authorities acquiesced to a degree of debate about legal categories, as ruled and ruler alike considered it a duty of vassals to petition and inform. The petition-and-response system influenced rulers' phrasing of both viceregal and royal decrees, allowing Spaniards, Indians, and others to create, contest, and complicate legal terms. ${ }^{143}$ As a result of this process, Indies legislation featured a hodgepodge of centuries-old and brand- new terms, which were unsystematic, often overlapping, and almost always vague.

Many commonly used categories could easily describe Spaniards and Indians simultaneously, for example, Christian (cristiano), vassal (vasallo), conquistador (conquistador) and local (natural). ${ }^{144}$ Spaniards and Indians could share honorific categories like 'sir' (don), 'lady' (doña), 'lord' (señor), and 'gentleman' (hidalgo). They also could fall into the same birth classifications: bastard (bastardo), child born out of wedlock (bijo natural), and legitimate (legitimo), and marital statuses such as bachelor (soltero), concubine (mancebo), and widow (viudo). ${ }^{145}$ Some born of Spanish-Indian unions might form part of either society, or neither, depending on the political context, social acceptance, and the opinion of outside observers. ${ }^{146}$

Labor, generally a defining factor in contemporaries' differentiations between Spaniards and Indians, was also complex. Each group could hold shared tax-exempt offices, including municipal positions like municipal official (regidor), scribe (escribano), local justice (alguacil), and others. Spaniards could fall into categories inspired by indigenous languages and practices, such as translator (nabuatlato) and tribute collector (calpisque). Indians were most

cacicazgo miisca en los años posteriores a la Conquista: del sihipkua al cacique colonial (1537-1575), (Bogotá: Instituto Colombiano de Antropología e Historia, 2010), 247-253, among many others.

143. Adrian Masters, "A Thousand Invisible Architects: Vassals, the Petition-and-Response System, and the Creation of Spanish Imperial Caste Legislation," Hispanic American Historical Review 98:3 (2018): $377-406$.

144. Tamar Herzog, "The Appropriation of Native Status: Forming and Reforming Insiders and Outsiders in the Spanish Colonial World," Rechtsgeschichte-Legal History 22 (2014): 140-149; Laura E. Matthew and Michel R. Oudijk, eds. Indian Conquistadors: Indigenous Allies in the Conquest of Mesoamerica (Norman: University of Oklahoma Press, 2007).

145. Enrique Mayer, The Articulated Peasant: Household Economies in the Andes (Boulder, CO: Westview Press, 2002), 91 .

146. Rappaport, Disappearing Mestizo. 
often tribute-paying serfs, but the legal reality regarding their professions and work responsibilities was also intricate. Documents contain numerous terms for tribute-exempt Indian lords such as tlatoani, yya toniñe, pipiltin, teuctle, orejón, toniñe, cacique, cihuapilli, and curaca. Indian municipal functionaries could also belong to categories like council leaders (gobernador, gobernadoryotl, cacique gobernador), officials (camayocs), financial officers (tesoreros, fiscales mayordomos), and recordkeepers (escribanos, tlacuilos, and quipocamayocs). ${ }^{147}$ There was an assortment of tribute and justice enforcers specific to Indians (mandón, capitán, merino, mayoral, tequitlato, tequitlato mayor, topil). ${ }^{148}$ Special religious functionaries like alms-gatherer (fiscal de iglesia and topil de la iglesia), as well as singers or cantores, join the list. ${ }^{149}$ All Indians falling within these categories were tribute-exempt. ${ }^{150}$

Commoners who did pay tribute might appear simply as indios, indios tributarios, macehuales, mitimaes, or in other categories, depending on the region and the context. In addition, there was a complex array of servant categories, including naborias, mayeques, tlalmaites, indios de servicio, yanaconas, and camaricos. ${ }^{151}$ Tributary status sometimes varied by labor type, such as mining, ranching, artisan work, river service, or domestic work, and also by region, depending on Indians' negotiations with local officials. Across all these categories came the dissecting force of sweeping rules about preventing lowlanders and highlanders (indios de tierra caliente, indios de tierra fría) from working outside of certain climates. Age, gender, marital status, wealth, physical fitness, and other considerations further complicated tribute arrangements. ${ }^{152}$

Through grace (gracia) petitions which established an array of special privileges for crown loyalists and virtuous vassals, some ethnicities and political confederations also managed to carve out a status somehow different from their neighbors, distinguishing Indians from other Indians. Certain groups like the Mexica, Tlaxcala, Cañaris, Chachas, Huancas, and Cuzcos received decrees promising total or partial tribute exemption and other benefits. ${ }^{153}$ Indian

147. Charles Gibson, Los aztecas bajo el dominio español (1519-1810), (Mexico City: Siglo XXI, 1978 [1964]), 178-187; Carmen Beatriz Loza, "De la classification des Indiens à sa réfutation en justice (Yucay, Andes Péruviennes, circa 1493-1574)," Histoire \& Mesure 12:3/4 (1997): 361-386, here 379.

148. Charles Gibson, Los aztecas, 178-187, 185.

149. Gibson, Los aztecas, 178, 186.

150. That is not to say that some officials did not attempt to tax them, however. Indeed, many Mexica complained of this. See for instance, Los indios mexicanos, 1576, AGI, México 100.

151. Gibson, Los aztecas, 156; Mayer, Articulated, 93; Beatriz Loza, "Classification," 379.

152. For an excellent 1590s overview of Indies' taxation of Indians and mestizos that captures this complexity, see Una cédula, 1590, AGNM, Colonial, Hospital de Jesús, leg. 383, exp. 5.

153. Udo Oberem, "Los Cañaris y la conquista española de la Sierra ecuatoriana, otro capítulo de las relaciones interétnicas en el siglo XVI," Journal de la Société des Américanistes 63 (1974): 263-274, here 263; Jaime Valenzuela Márquez, "Indígenas andinos en Chile Colonial: inmigración, inserción espacial, integración económica y movilidad social (Santiago, siglos XVI-XVII)," Revista de Indias, 70:250 (2010): 749-778. 
caciques, governors, and leaders, both men and women, also petitioned constantly for personal and family licenses to carry arms, dress like Spaniards, and ride horses, among other privileges, which simultaneously reinforced and eroded Spanish-Indian differences. ${ }^{154}$ These petitions for privilege and the resulting decrees, perhaps more than any other feature of the Spanish justice system, reveal authorities' flexible attitudes about cultural and legal segregation.

Inversely, many officials demoted certain Indians whose behaviors they felt gravely transgressed crown policies, the common good, or divine and natural law, and sometimes for other considerations. An array of special semi-deviant or deviant categories arose to describe illegitimate lords and others who sought to escape tribute and other duties (caciques intrusos, caciques postizos, forasteros, buidos, gente suelta, ladinos). ${ }^{155}$ Indians who refused to submit to Spanish rule fell into another spectrum of legal categories that condoned their enslavement, like cannibal (canibal), runaway (indio cimarrón), and war Indian (indio de guerra). During some periods of armed conflict, ethno-legal categories like Araucano, Chichimec, and Chiriguano became all but synonymous with enemy belligerents. And ecclesiastical judges and early inquisitors sought to uproot those they categorized as spellcasters (bechiceros), warlocks (brujos), witches (brujas), and others.

Even this very superficial treatment of a small number of institutions and categories shows that the crown, far from drawing a firm line between Spaniards and Indians or seeking to treat either group as a legal monolith, allowed for vassals to co-create an insurmountably messy system, or quasi-system, of classification and action. This ever-changing structure superficially preserved the Spanish-Indian legal dichotomy but allowed massive areas of overlap and internal divisions that beneath the surface look little like the two-republics model. Segregation in both legislation and practice must therefore be rethought, beyond the Mörner Thesis. Such rethinking also involves consideration of the status of those whom observers considered neither fully Spanish nor Indian. One recent study, following Mörner, defines the republics as "two self-contained and fully segregated social or territorial units, one populated by Indians, the other by Spaniards, mestizos, Africans, criollos,

154. For innumerable petitions of this kind, see the sixteenth century viceregal edicts in AGNM, Colonial, Indios 2 to 6.2; and Robert C. Schwaller, “'For Honor and Defence:' Race and the Right to Bear Arms in Early Colonial Mexico," Colonial Latin American Review, 21:2 (2012): 239-266.

155. Cristóbal Landázuri, Visita y numeración, 76; Gibson, Los aztecas, 149; Karen M. Powers, "Resilient Lords and Indian Vagabonds: Wealth, Migration, and the Reproductive Transformation of Quito's Chiefdoms, 1500-1700," Ethnohistory 38:3 (1991): 225-249; Karen Vieira Powers, "The Battle for Bodies and Souls in the Colonial North Andes: Intraecclesiastical Struggles and the Politics of Migration," Hispanic American Historical Review 75:1 (1995): 31-56, here 31-34. 
and other non-Indian subjects." 156 Many scholars have consequently depicted an overzealous Catholic monarchy bent on segregation but impotent against vassals' unstoppable libidos. The puritanical crown was overwhelmed as picaro miscegenation won the day. ${ }^{157}$

Undoubtably, Spanish-Indian separation was the goal of many royal and viceregal laws, yet scholars have associated segregation with the two republics far too forcefully. ${ }^{158}$ As I have suggested above, even within the narrow space of writings dealing conceptually with republics, neither the crown nor its vassals were always of one mind about how to proceed with such an undertaking. Congregation of Indians into towns was not an enterprise dedicated exclusively to segregation, and it often had the opposite finality: to bring Indians closer to Spanish administrative and ecclesiastical control. Marriage between any vassals remained legal. ${ }^{159}$ Viceregal, municipal, and communal policies and exceptions variously promoted and undermined separation, playing a major part that few scholars take into consideration. ${ }^{160}$ The trope of systemic 'failed segregation' and its concomitant 'colonial impossibility' are overdue for serious reappraisals. $^{161}$

Questioning the Mörner Thesis of the two republics concerns more than Spaniards and Indians. According to scholarship influenced by the Swedish historian, the crown manically produced abundant legislation on those partly or entirely outside of Spanish and Indian groups, such as mulattos (part Afro-descendants), zambahigos (part Afro-descendant, part Indian), mestizos, and others. For many historians, this proliferation of terms can be attributed to the crown's stubborn adherence to the strict dual republics system-a

156. Tavárez, "República," 1255; Schwaller, Géneros, argues (57) that the "lived reality of colonial life did not conform to the legal expectation" of the Two Republics.

157. Deborah E. Kanter, “'Their Hair was Curly': Afro-Mexicans in Indian Villages, Central Mexico, 1700-1820, in Crossing Waters, Crossing Worlds: The African Diaspora in Indian Country, Tiya Miles and Sharon P. Holland, eds. (Durham: Duke University Press, 2006), 167; Margadant, "Spanish Colonial Policy," 424; Christopher H. Lutz, Santiago de Guatemala, 1541-1773: City, Caste, and the Colonial Experience (Norman: University of Oklahoma Press, 1997 [1994]), 47; Castillo Palma, Cholula, 30-31.

158. O'Hara, Flock, 29-31; Cope, Limits, 3, 16; J. I. Israel. Race, Class, and Politics in Colonial Mexico, 14-15; López-Portillo, 'Another Jerusalem,' 19; Tavárez, “República”; Schwaller, Géneros, 56, 80-81; Nemser, Infrastructures, 102.

159. Borah, Insurance, 29.

160. For the power of Indies municipalities to determine citizenship in the 1500s, see Tamar Herzog, Defining Nations: Immigrants and Citizens in Early Modern Spain and Spanish America (New Haven: Yale University Press, 2003), 52-54.

161. For top-down models, see John Huxtable Elliott, Empires of the Atlantic World: Britain and Spain in America, 1492-1830 (New Haven: Yale University Press 2006), 83; Francisco Bethencourt, Racisms: From the Crusades to the Twentieth Century (Princeton: Princeton University Press, 2013), 207; Alcira Dueñas. Indians and Mestizos in the "Lettered City": Reshaping Justice, Social Hierarchy, and Political Culture in Colonial Peru (Boulder: University of Colorado Press, 2010), 238; María Elena Martínez, Genealogical Fictions: Limpieza de Sangre, Religion, and Gender in Colonial Mexico (Stanford University Press, 2008), 92; and González González, "Mecenazgo y literatura," 17. 
"disconnect between ideal and reality." 162 In other words, the failure of the Two Republics as a sociolegal system engendered the infamous Spanish imperial caste system.

For a crown "whose thinking could only fathom a society composed of "two republics," where would the others fit? ${ }^{163}$ My research has uncovered only a few documents mentioning Afro-descendants and other non-Indians that also employed explicitly the concept of the republic. All date from the final third of the sixteenth century. One, a 1576 letter by the royal attorney Licenciado Ramírez de Cartagena, reported that there were not enough laborers in the "republic of Spaniards" and stated that the crown should look elsewhere, to non-Spanish, non-Indian "idle peoples" like "blacks . . . mulattos and mestizos and zambahigos."

Other writings tended to make a very distinct argument for non-Indians' membership in the republic of the Spaniards. Panama's municipal ordinances, which the crown ratified in 1571, described a "great quantity of free black men and women in this city and republic" who "cause much harm"-especially because city officials suspected some aided runaway slaves. Officials were to expel free Afro-descendants to a nearby island. ${ }^{165}$ These subjects were part of the town-republic, the argument went, but should form their own community regardless. The Mexican viceroy issued a 1574 edict stating that officials should undertake a census with all "black men and women, [and] free vagabond mulattos and mulattas" in the "republic," presumably meaning Mexico itself. According to this edict, "the republic of Spaniards and Indians" was "defrauded" by Afro-descendants' refusal to pay taxes and take up professions. ${ }^{166}$ This was the only text I managed to locate which explicitly envisioned a joint Spanish-Indian republic that explicitly excluded Afro-descendants and others.

Another group of writers offered the opposite argument. The Franciscans of Mérida, Yucatán, wrote in 1576 that "there is great hunger in the republic of the Spaniards and Indians," and that "Spanish republic and the blacks and

162. Matthew Restall, The Black Middle: Africans, Mayas, and Spaniards in Colonial Yucatan (Stanford: Stanford University Press, 2009), 91; Karen Spalding, Huarochiri Andean Society under Inca and Spanish Rule (Stanford: Stanford University Press, 1984), 296; Vinson, Before Mestizaje, 3-4.

163. Andrés Lira and Luis Muro, "El siglo de la integración," 371-470, Historia general de México, vol. 1 (Mexico City: Colmex, 1988), here 377; Aude Argouse, "Soi tal mestizo abido y tenido por tal desde que nasi': peticiones indígenas de cambio de fuero, Cajamarca, Perú, 1642-1674," Colonial Latin American Historical Review 16:4 (2007): 401-427, here 401-404; Berquist Sole, "Race and Rule," 632-633.

164. Con la flota, 1576, AGI, Lima 124, 3r.

165. Royal ordinance, 1571, AGI, Panama 236, L.10, 210v-214r, esp. $213 \mathrm{r}$. 19, N.142

166. Don Martín Enrríquez, 1574, AGI, Patronato 182, R.49. For a copy of the same document, see AGI, México 
mulattos" ate, whereas "the republic of the natives" was left starving. ${ }^{167}$ This equivocal use of the 'republic of Spaniards' implied, but did not clarify, where Afro-descendants belonged: within the Spanish republic, not the Indian. Yet Afro-descendants were sometimes deeply integrated into Indian republics, a fact officials did not always ignore. In 1586 the president of Charcas stated that "mulattos and zambahigos" were "a damned generation born from black men and Indian women . . . cruel executioners of the miserable Indians.” He proposed integrating them into Spanish municipal jurisdictions as tradesmen. This would prevent them from causing harm "in the republics, mainly among Indians"- that is, in Indian town-republics. ${ }^{168}$ The president implied that this "damned generation" could nonetheless coexist with urban Spaniards and Indians if its members took up honest vocations.

For certain writers, all, including Afro-descendants and non-Indians, shared one republic. Friar Gaspar de Recarte noted in a 1584 report to the crown that "Spaniards and Indians make in this Indies one republic," and that officials should not abuse Indians "as if they were slaves." There were "many blacks, mestizos, and free mulattos, as well as other poor Spaniards and officials which the republic should compel" to work, instead of Indians. ${ }^{169}$ All thus formed a single meta-republic of the Indies, making them responsible for forgoing individual interests for the common good. Friar Miguel de Benavides similarly reported to the crown in 1596 that Mexico's entire labor burden fell to Indians, though able-bodied "Spaniards and free blacks and mulattos and mestizos who are all part of this republic" could share this load. ${ }^{170}$

Determining what Afro-descendant petitioners made of their place within these overlapping political communities is difficult. The petition-and-response system does provide one clue. One 1571 royal decree stated that the crown had been informed by "the mulattos of that land" that traveling Indian merchants (pustecas) brought "much harm" on the "republic." Considering the geographical mobility of the pustecas, we can surmise that some of Mexico's mulatto petitioners viewed themselves as part of the viceroyalty-republic. ${ }^{171}$ This finding builds upon Chloe Ireton's research into Afro-descendants' and Spaniards' understanding of many black vassals not as outsiders but as members of the Indies' many Old Christian political communities. ${ }^{172}$

167. El memorial, 1576, AGI, México 101.

168. Conforme al tiempo, 1586, AGI, Charcas 16, R.25, N.137.

169. Tractado del servicio personal, 1584, AGI, Patronato 183, N.1, R.12.

170. Parecer de Fray Miguel de Benavides, AGI, Indiferente 2987, 42r.

171. Royal decree, 1571, AGI, México 1090, L.6, 247r.

172. Chloe Ireton, "'They Are Blacks of the Caste of Black Christians': Old Christian Black Blood in the Sixteenthand Early Seventeenth-Century Iberian Atlantic," Hispanic American Historical Review 97:4 (2017): 579-612. 
While self-described mestizos rarely formed political groups, in 1588 a legal representative of 150 part-Indian, part-Spanish petitioners named Pedro Rengifo informed the king and the council that "persons born in the Provinces of Peru from Spaniards and Indians, which are called mestizos," were a "part of the republic," albeit without defining which type of republic he meant. ${ }^{173}$ Afro-descendants and mestizos thus occupied ambiguous roles in the era's conceptualization of republics. Nonetheless, republic-thinking did not cause their legal predicaments a priori. Nor were non-Spaniards barred from participating in the broader debate about the nature of their belonging within Indies society.

\section{CONCLUSIONS}

Drawing from extensive archival research, this article has come to four overarching conclusions about how ideas of human difference and community functioned within Indies society. First, I have provided an understanding of how republics functioned, one that largely invalidates Magnus Mörner's profoundly influential vision of the segregationist Two Republics. This has implications for historiographical models of Spanish imperial governance. The Mörner Thesis mischaracterized how the king, the Council of the Indies, and other officials ruled, depicting their actions and thoughts as highly interventionist, systematic, and aloof to Indies realities. ${ }^{174}$ This article demonstrates the contrary: sixteenth-century officials did not systematically attempt to uniformly and rigidly segregate Spaniards and Indians into separate republics, even on a conceptual plane, during the sixteenth century. Only a fraction embraced a conceptually binary and segregated model of republics. In fact, when officials did invoke what we might call the Two Republics model, they most often did so to emphasize the shared interests of Spaniards and Indians. This corroborates what others have argued for other facets of early Indies rule: that officials were simultaneously quite passive and quite flexible, and royal legislation far from consistent and methodical. ${ }^{175}$

173. Pedro de Rengifo, AGI, Lima 126, 114r.

174. See Mörner, Corona; Alcira Dueñas, "The Lima Indian Letrados: Remaking the República de Indios in the Bourbon Andes," The Americas 72:1 (2015): 55-75; Mark Thurner, From Two Republics to One Divided: Contradictions of Postcolonial Nationmaking in Andean Peru (Durham: Duke University Press, 1997), 5; and Borah, Insurance, 29.

175. Arndt Brendecke, Imperio e información: funciones del saber en el dominio colonial español. Griselda Mársico, trans. (Madrid: Iberoamericana, 2012); Victor Tau Anzoátegui, Casuismo y sistema: indagación histórica sobre el espiritu del Derecho Indiano (Buenos Aires: Instituto de Investigación de Historia del Derecho, 1992); John Leddy Phelan, "Authority and Flexibility in the Spanish Imperial Bureaucracy." Administrative Science Quarterly 5:1 (1960): 47-65. See also Thomas Duve's excellent historiographical essay, "Indigenous Rights in Latin America: A Legal Historical Perspective," 1-20, Oxford Handbook of Historical Legal Research, Markus Dubber and Chris Tomlins, eds. (Oxford: Oxford University Press, 2017). 
Second, this article has demonstrated how vassals, officials, and jurists used the concept of the republic to envision the Indies as a composite of many communities, both conceptual and tangible. Vassals used the term creatively within a nested and heterogenous framework that encompassed municipal, provincial, viceregal, Indies, monarchical, and Christian spheres (among others). This supports other scholars' contentions that the Anglocentric historiography on republic-thinking excludes this rich Spanish-imperial tradition. Even the few scholars who have explored this topic have focused almost entirely on jurists' and priests' visions of the republic. ${ }^{176}$ As I have shown, however, many indigenous communities, as well as some Afro-descendant and mestizo subjects, employed this notion to frame their place in the empire, engaging in non-elite, non-Spanish ontological and intellectual enterprises that historians are increasingly beginning to recognize. ${ }^{177}$

Third, while this article maintains that the Spanish-Indian binary was extraordinarily important in early Indies society, it maintains that the Mörner Thesis elides many of its social and institutional complexities, beyond the two-republics concept itself. Institutions and officials ostensibly exclusive to Spaniards or Indians had more complex operations than Mörner's model allows for. The crown did not seek segregation consistently. It simultaneously allowed Spanish-Indian marriages, cohabitation, economic association, conversion, and other actions that wove these groups together. These two legal categories also had important semantic overlaps with one another, as well as many internal complexities. The rise of a so-called caste system featuring countless legal categories such as mestizo and mulatto did not occur because of the libidinous breakdown of the Two Republics, but because of petitioners' constant agonistic efforts to diminish their opponents.

These three points converge in a fourth and final conclusion: that historians must show extreme caution when embracing aesthetically elegant and conceptually convenient models for theorizing the early modern Spanish Empire. Instead, they might more fruitfully seek models better suited for explaining its complexity. This article has stopped far short of providing a comprehensive alternative framework but will hopefully buttress future research in this direction. If we explore Spanish-Indian legal dualities and social relations through the lens of the Spanish Empire's absolutist forms of nested and hierarchical but often messy multi-normativity and pluri-jurisdictionality, which $275-296$.

176. Quijano, "Pensar la comunidad," 27-28; Quijano, Repúblicas de la monarquía, 55; Lomné, "Regeneración,"

177. Ethelia Ruiz Medrano and Susan Kellogg, eds. Negotiation within Domination: New Spain's Indian Pueblos Confront the Spanish State (Boulder: University Press of Colorado, 2010); Puente Luna, Andean Cosmopolitans; Dueñas, "Lettered City." 
invited petitioners' constant engagement with law-giving institutions, and if we take into consideration the various institutions that granted gracia exceptions to norms to individuals and groups, the Indies' many complex categories become, if not simpler, at least more comprehensible. Already, many are headed down this path. ${ }^{178}$

The reformer-petitioner Martín González de Cellorigo provided an apt republican metaphor for this early modern messiness. In a 1600 treatise he noted that the global republic was "a just government of many families and their common good," ruled over by a monarch and comprised of a complex union resembling a human body. ${ }^{179}$ But if the king was "loaded with petitions, reports, and opinion pieces," as Emperor Charles V and King Philip II had been in the previous century, and subsequently "promulgated multitudes of laws," González warned, the republic would become turgid and disorderly. ${ }^{180}$ Cellorigo complained that the Spanish imperial republic, rather than resembling an instrument of "harmonious sweetness," was a "labyrinth of infinite errors." ${ }^{181}$ Perhaps as historians we need not seek out harmony in early modern Spain's policies so aggressively. Rather, as we wander the labyrinths of the Indies' disorderly categories, we might instead train our ears for their normative cacophony.

University of Tübingen, SFB-923, F-04

ADRIAN MASTERS (iD

Tübingen, Germany

adrianmmasters@gmail.com

178. For definitions of legal pluralism and multi-normativity, see Ralf Seinecke, "Rechtspluralismus in der Rechtsgeschichte," Rechtsgeschichte-Legal History 25 (2017), 215-228; and Thomas Duve, "Was ist >Multinormativität<? - Einfũhrende Bemerkungen,” Rechtsgeschichte-Legal History 25 (2017): 88-101; and Deardorff, "Convivencia," 190.

179. González de Cellorigo, Memorial, 88.

180. González de Cellorigo, Memorial, 162.

181. González de Cellorigo, Memorial, 103, 123. 